Article

\title{
Corrosion Resistance of Mild Steel Coated with Phthalimide-Functionalized Polybenzoxazines
}

\author{
Kamal I. Aly ${ }^{1}{ }^{\oplus}$, Abdulsalam Mahdy ${ }^{1,2}$, Mohamed A. Hegazy ${ }^{3}{ }^{\circledR}$, Nayef S. Al-Muaikel ${ }^{4}$, \\ Shiao-Wei Kuo ${ }^{5}$ (D) and Mohamed Gamal Mohamed $1,5, * \mathbb{D}$ \\ 1 Polymer Research Laboratory, Chemistry Department, Faculty of Science, Assiut University, Assiut 71516, Egypt; \\ kamalaly@aun.edu.eg (K.I.A.); abdualsalam735@yahoo.com (A.M.) \\ 2 Chemistry Department, Faculty of Education \& Science, Rada'a Al-Baydha University, Al-Baydha 38018, Yemen \\ 3 Petrochemicals Department, Egyptian Petroleum Research Institute (EPRI), Nasr City, Cairo 11727, Egypt; \\ mohamedhegazy997@gmail.com \\ 4 Chemistry Department, College of Science, Al-Jouf University, Skaka 72388, Al-Jouf, Saudi Arabia; \\ n_almuaikel@hotmail.com \\ 5 Department of Materials and Optoelectronic Science, Center of Crystal Research, National Sun Yat-Sen University, \\ Kaohsiung 804, Taiwan; kuosw@faculty.nsysu.edu.tw \\ * Correspondence: mgamal.eldin34@gmail.com
}

Received: 23 October 2020; Accepted: 17 November 2020; Published: 19 November 2020

\begin{abstract}
Herein, we synthesized two new phthalimide-functionalized benzoxazine monomers, $p$ PP-BZ and oPP-BZ, through Mannich reactions of 2-(4-hydroxyphenyl)isoindoline-1,3-dione $(p \mathrm{PP})$ and 2-(2-hydroxyphenyl)isoindoline-1,3-dione $(o \mathrm{PP})$, respectively, with $p$-toluidine and paraformaldehyde. The structures of these two monomers were confirmed using Fourier transform infrared (FTIR) and nuclear magnetic resonance spectroscopy. We used differential scanning calorimetry, FTIR spectroscopy, and thermogravimetric analysis to study the polymerization behavior and thermal stability of the monomers and their corresponding polybenzoxazines. Poly $(p P P-B Z)$ and poly(oPP-BZ) were formed on mild steel (MS) through spin-coating and subsequent thermal curing polymerization. We used various corrosion testing methods to examine the effect of the curing temperature on the corrosion resistance of the coated MS samples in $3.5 \mathrm{wt} . \%$ aqueous solution of $\mathrm{NaCl}$. Among our tested systems, the corrosion rate reached a low of $2.78 \mu \mathrm{m} \cdot \mathrm{Y}^{-1}$ for the MS coated with poly $(p \text { PP-BZ })_{180}$ (i.e., the coating that had been cured at $180^{\circ} \mathrm{C}$ ); this value is much lower than that $\left(4.8 \mu \mathrm{m} \cdot \mathrm{Y}^{-1}\right)$ reported for a maleimide-based benzoxazine compound (MI-Bz)/33 wt. $\%$ ACAT (amine-capped aniline trimer) blend. Thus, the incorporation of the imide functional group into the PBZ coatings is an effective strategy for affording high-performance corrosion resistance.
\end{abstract}

Keywords: polybenzoxazine; ring-opening polymerization; mild steel; polymer coatings

\section{Introduction}

Intra and intermolecular hydrogen bonds among their heterocyclic polymer chains impart polybenzoxazines (PBZs) with many useful properties, including high thermal stability, high glass transition temperatures, high char yields, near-zero shrinkage upon polymerization, low water absorption, low flammability, excellent mechanical and dielectric properties, low surface free energies, and high water contact angles (WCAs) [1-10]. Benzoxazine monomers, which are generally prepared through Mannich reactions of phenols, primary amines, and formaldehyde, can polymerize simply through thermal curing without any catalyst and without releasing any by-products during their ring-opening polymerization (ROP) [11-20]. Aromatic polyimides are also high-performance polymers that display high thermal stability, excellent mechanical properties, and high chemical resistance [21]; 
their inert imide rings and strong interchain interactions make them useful in, for example, plastics, films, laminating resins, insulating coatings, and high-temperature structural adhesives [22]. The high degrees of molecular design flexibility and functionalization of benzoxazine monomers can be exploited to improve the performance of these monomers and their resulting PBZs, expanding their opportunities for potential applications. For example, the introduction of a sulfonic acid unit into the benzoxazine backbone has led to corresponding PBZs displaying good thermal stability, low methanol permeability, and excellent acid resistance, making them promising materials for proton exchange membranes in direct methanol fuel cells [23]. Furthermore, PBZ/polyimide-blend films have exhibited good toughness and thermal stability [24]. Organic coatings are often employed to protect iron and mild steel (MS) against corrosion by preventing corrosive agents from reaching the substrate and by acting as barriers against a direct current [25]. The protective barrier properties of a coating are typically characterized in terms of the rates of transport of water and ions through its polymer network [26]. The incorporation of particular functional groups into PBZ coatings can enhance their adhesion to metal substrates and improve the corrosion resistance; for example, the charge transfer resistance $\left(R_{\mathrm{ct}}\right)$ of MS coated with a silane-based PBZ $\left(1.2891 \mathrm{M} \Omega \cdot \mathrm{cm}^{2}\right)$ was higher than that of the uncoated MS $\left(0.0396 \mathrm{M} \Omega \cdot \mathrm{cm}^{2}\right)$ [27]. Recently, PBZ-based electroactive species have been used to form protective passive oxide layers on steel substrates to prevent their corrosion [28-30]. For example, coating MS with PBA-ddm has resulted in excellent corrosion resistance and a decrease in the corrosion current by two orders of magnitude relative to that of the uncoated MS [31]. Phthalimide materials have been evaluated as anticorrosive coatings for MS in $1 \mathrm{~mol} \cdot \mathrm{L}^{-1} \mathrm{H}_{2} \mathrm{SO}_{4}$; they displayed anticorrosion activity arising from their $\pi$-delocalized phthalimide systems and lone pairs of electrons on their $\mathrm{N}$ and $\mathrm{O}$ atoms [32]. Herein, we report the synthesis of two novel phthalimide-functionalized benzoxazine monomers, $p$ PP-BZ and $o$ PP-BZ. First, we prepared the phthalimide-functionalized phenols $p$ PP and $o$ PP by reacting phthalic anhydride with para- and ortho-aminophenol, respectively, in acetic acid. We then obtained $p$ PP-BZ and $o$ PP-BZ from the reactions of $p \mathrm{PP}$ and $o \mathrm{PP}$, respectively, with $p$-toluidine and paraformaldehyde in 1,4-dioxane. Fourier transform infrared (FTIR) and nuclear magnetic resonance (NMR) spectroscopy confirmed the chemical structures of these benzoxazine monomers. We used differential scanning calorimetry (DSC), FTIR spectroscopy, and thermogravimetric analysis (TGA) to study the polymerization behavior of the oxazine units in these benzoxazine monomers and the thermal stability of their corresponding polymers after curing at various temperatures. Furthermore, we measured open-circuit potentials $\left(E_{\text {ocp }}\right)$, polarization, and WCAs and employed electrochemical impedance spectroscopy (EIS) to investigate the effect of the curing temperature on the corrosion resistance of poly ( $p$ PP-BZ) and poly (oPP-BZ) coatings on MS in $3.5 \mathrm{wt} . \%$ aqueous solution of $\mathrm{NaCl}$.

\section{Materials and Methods}

\subsection{Materials}

$p$-Toluidine (97\%), o-aminophenol (98\%), phthalic anhydride $\left[\mathrm{C}_{6} \mathrm{H}_{4}(\mathrm{CO})_{2} \mathrm{O}\right]$, paraformaldehyde $\left(\left(\mathrm{CH}_{2} \mathrm{O}\right)_{n}, 99 \%\right), 1,4$-dioxane, ethyl acetate $(\mathrm{EtOAc})$, magnesium sulfate $\left(\mathrm{MgSO}_{4}\right)$, acetic acid $\left(\mathrm{CH}_{3} \mathrm{COOH}\right)$, $p$-toluidine, sodium carbonate $\left(\mathrm{Na}_{2} \mathrm{CO}_{3}\right)$, and chloroform $\left(\mathrm{CHCl}_{3}\right)$ were purchased from Acros. All chemicals were used as received without further purification.

\subsection{Synthesis of 2-(4-Hydoxyphenyl)isoindoline-1,3-dione ( $p P P)$}

$p$ PP was prepared according to a previously reported method [5]. Yield: $90 \%$. M.p.: $299{ }^{\circ} \mathrm{C}$. ${ }^{1} \mathrm{H}$ NMR (400 MHz, DMSO- $d_{6}, \delta$, ppm, Figure S1): $9.70(\mathrm{OH}), 6.75-7.90(8 \mathrm{H}, \mathrm{ArH})$. FTIR $\left(\mathrm{KBr}, \mathrm{cm}^{-1}\right)$ : 3413 (OH stretching), 1778, 1717 (imide I), 1397 (imide II, CN stretching), 722 (C=O bending). 


\subsection{Synthesis of 2-(2-Hydoxyphenyl)isoindoline-1,3-dione (oPP)}

$o$ PP was prepared according to a previously reported method [5]. Yield: $95 \%$. M.p.: $220{ }^{\circ} \mathrm{C}$. ${ }^{1} \mathrm{H}$ NMR $\left(400 \mathrm{MHz}\right.$, DMSO- $d_{6}, \delta$, ppm, Figure S2): 6.75-7.9 $(8 \mathrm{H}, \mathrm{ArH}), 9.70(\mathrm{OH})$. FTIR $\left(\mathrm{KBr}, \mathrm{cm}^{-1}\right)$ : 3379 (OH stretching), 1772, 1720 (imide I), 1389 (imide II, CN stretching), 722 (C=O bending).

\subsection{Synthesis of 2-(3-(p-Tolyl)-3,4-dihydro-2H-benzo[e][1,3]oxazin-6-yl)isoindoline-1,3-dione (pPP-BZ)}

A solution of $p$-toluidine $(1.0 \mathrm{~g}, 0.0093 \mathrm{~mol})$ and paraformaldehyde $(0.80 \mathrm{~g}, 0.030 \mathrm{~mol}) \mathrm{in}$ 1,4-dioxane $(30 \mathrm{~mL})$ was stirred under reflux at $70{ }^{\circ} \mathrm{C}$ for $30 \mathrm{~min}$ in a $100-\mathrm{mL}$ round-bottom flask. $p$ PP $(2.00 \mathrm{~g}, 0.0083 \mathrm{~mol})$ was added and the mixture was then heated at $110^{\circ} \mathrm{C}$ for $24 \mathrm{~h}$. The solution was cooled to room temperature and the solvent evaporated using a rotary evaporator. The residue was dissolved in EtOAc and washed three times with $1 \mathrm{~N} \mathrm{NaOH}$ and twice with water. The organic phase EA was dried $\left(\mathrm{MgSO}_{4}\right)$ and concentrated using a rotary evaporator. Finally, the residue was precipitated in hexane $(100 \mathrm{~mL})$ to give a white powder: yield: $55 \%$. FTIR $\left(\mathrm{KBr}, \mathrm{cm}^{-1}\right): 1778,1717$ (imide I), 1494 (stretching of trisubstituted benzene ring), 1385 (imide II), 1227 (COC symmetric stretching), 1014 (CN asymmetric stretching), 925 (out-of-plane $\mathrm{CH}$ bending). ${ }^{1} \mathrm{H} \mathrm{NMR}\left(\mathrm{CDCl}_{3}, \delta, \mathrm{ppm}\right): 4.5\left(\mathrm{~s}, \mathrm{ArCH}_{2} \mathrm{~N}\right)$, $5.2\left(\mathrm{~s}, \mathrm{OCH}_{2} \mathrm{~N}\right), 6.75-7.9(\mathrm{ArH}, 14 \mathrm{H}) .{ }^{13} \mathrm{C} \mathrm{NMR}\left(\mathrm{CDCl}_{3}, \delta, \mathrm{ppm}\right): 20\left(\mathrm{CH}_{3}\right), 50\left(\mathrm{NCH}_{2} \mathrm{Ar}\right.$ oxazine ring), $80\left(\mathrm{OCH}_{2} \mathrm{~N}\right), 116-152$ (aromatic carbon nuclei), $167(\mathrm{C}=\mathrm{O})$.

\subsection{Synthesis of 2-(3-(p-Tolyl)-3,4-dihydro-2H-benzo[e][1,3]oxazin-8-yl)isoindoline-1,3-dione (oPP-BZ)}

A solution of $p$-toluidine $(1.0 \mathrm{~g}, 0.0093 \mathrm{~mol})$ and paraformaldehyde $(0.80 \mathrm{~g}, 0.030 \mathrm{~mol})$ in 1,4-dioxane $(30 \mathrm{~mL})$ was stirred under reflux at $70{ }^{\circ} \mathrm{C}$ for $2 \mathrm{~h}$ in a $100-\mathrm{mL}$ round-bottom flask. oPP $(2.0 \mathrm{~g}, 0.0083 \mathrm{~mol})$ was added and then the mixture was heated at $110{ }^{\circ} \mathrm{C}$ for $6 \mathrm{~h}$. The solution was cooled to room temperature and the solvent evaporated using a rotary evaporator. The residue was dissolved in EtOAc and washed three times with $1 \mathrm{~N} \mathrm{NaOH}$. The organic phase was dried $\left(\mathrm{MgSO}_{4}\right)$ and concentrated using a rotary evaporator. Finally, the residue was precipitated in hexane $(100 \mathrm{~mL})$ to give brown crystals. Yield: $90 \%$. FTIR $\left(\mathrm{KBr}, \mathrm{cm}^{-1}\right)$ : 1772, 1720 (imide I group) 1507 (stretching of trisubstituted benzene ring), 1386 (imide II, CN stretching), 1209 (COC antisymmetric stretching), 929 (out-of-plane $\mathrm{CH}$ bending). ${ }^{1} \mathrm{H}$ NMR $\left(400 \mathrm{MHz}, \mathrm{CDCl}_{3}, \delta, \mathrm{ppm}\right): 4.5\left(\mathrm{~s}, \mathrm{ArCH}_{2} \mathrm{~N}\right.$, oxazine), $5.2\left(\mathrm{~s}, \mathrm{OCH}_{2} \mathrm{~N}\right.$, oxazine), 6.8-7.8 $(\mathrm{ArH}, 14 \mathrm{H}) .{ }^{13} \mathrm{C} \mathrm{NMR}\left(400 \mathrm{MHz}, \mathrm{CDCl}_{3}, \delta, \mathrm{ppm}\right): 20$ (Me group in $p$-toluidine), $50\left(\mathrm{NCH}_{2} \mathrm{Ar}\right)$, $80\left(\mathrm{OCH}_{2} \mathrm{~N}\right), 119-150$ (aromatic carbon nuclei), $166(\mathrm{C}=\mathrm{O})$.

\subsection{Preparation of poly( $p P P-B Z)$ and poly (oPP-BZ)}

The monomers $p$ PP-BZ and $o$ PP-BZ were polymerized through thermally induced ROP to form phenolic structures featuring a Mannich base bridge $\left(\mathrm{CH}_{2} \mathrm{NRCH}\right)$. The cross-linking of each sample was performed using the following curing program: $150{ }^{\circ} \mathrm{C}(2 \mathrm{~h}), 180^{\circ} \mathrm{C}(2 \mathrm{~h}), 210^{\circ} \mathrm{C}(2 \mathrm{~h})$; slow cooling to ambient temperature.

\subsection{Preparation of $M S$ Samples Coated with poly( $P P P-B Z)$ and poly (oPP-BZ)}

The low-carbon MS used in this study had the following chemical composition: $0.19 \% \mathrm{C}$, $0.94 \% \mathrm{Mn}, 0.05 \% \mathrm{Si}, 0.022 \% \mathrm{Cu}, 0.009 \% \mathrm{P}, 0.004 \% \mathrm{~S}, 0.014 \% \mathrm{Ni}, 0.034 \% \mathrm{Al}, 0.009 \% \mathrm{Cr}, 0.016 \% \mathrm{~V}$, $0.003 \% \mathrm{Ti}$, and $98.709 \% \mathrm{Fe}$ [33]. The MS surface was polished with emery paper to remove its surface oxide layer. The MS surface was washed with $\mathrm{EtOH}$ and acetone and then dried. The monomers $p$ PP-BZ and oPP-BZ were dissolved separately in $\mathrm{CHCl}_{3}$ at $100 \mathrm{~g} \cdot \mathrm{L}^{-1}$. Each solution was spin-coated onto the MS surface and then dried at room temperature for $24 \mathrm{~h}$. The coated samples were cured at temperatures of 150,180 , and $210^{\circ} \mathrm{C}$ for $2 \mathrm{~h}$ for each curing stage. The thickness (ca. $5 \mu \mathrm{m}$ ) of the coating was determined by measuring each MS sample with a micrometer caliper before and after coating. The coated samples are named herein as poly $(p \text { PP-BZ })_{150}$, poly $(p P P-B Z)_{180}$, poly $(p \text { PP-BZ })_{210}$, poly $(o \text { PP-BZ })_{150}$, poly $(o P P-B Z)_{180}$, and poly $(o \text { PP-BZ })_{210}$. 


\subsection{Corrosion Tests}

The corrosion resistance of each of the prepared coatings (cured at 150,180 , or $210^{\circ} \mathrm{C}$ ) was examined in terms of open-circuit potentials $\left(E_{\text {ocp }}\right)$, potentiodynamic polarization, and EIS, performed using a Voltalab 40 PGZ 301 instrument controlled by VoltaMaster 4 software (Radiometer Analytical SAS, Lyon, France). All samples were immersed in $3.5 \mathrm{wt} . \%$ aqueous solution of $\mathrm{NaCl}$ at ambient temperature for $30 \mathrm{~min}$. The electrochemical cells included a saturated calomel electrode (SCE) as the reference electrode, a platinum wire as the counter electrode, and an uncoated or coated MS sample as the working electrode. The scanning potential of polarization measurements was $\pm 250 \mathrm{mV}$ of the open-circuit potential at a scan rate of $0.2 \mathrm{mV} \cdot \mathrm{s}^{-1}$. EIS was performed in the frequency range between $100 \mathrm{kHz}$ and $0.01 \mathrm{~Hz}$; EIS analysis was performed using ZSimpwin software. The electrochemical experiments were performed three times for each tested sample to obtain greater accuracy and reproducibility of the experimental results, and mean values were recorded.

\section{Results and Discussion}

\subsection{Synthesis of $P P P-B Z$ and $o P P-B Z$}

The para- and ortho-phthalimide-functionalized benzoxazine monomers were synthesized through reactions of the phthalimide-functionalized phenols $p$ PP and oPP, respectively, $p$-toluidine, and paraformaldehyde in 1,4-dioxane, as presented in Figure 1c,d. The ring-closing reaction of $o$ PP-BZ monomer was much easier than $p$ PP-BZ, because of the existence of intermolecular hydrogen bond in $o \mathrm{PP}$, which accelerates the ionization $\mathrm{OH}$ group during stages forming of $o \mathrm{PP}-\mathrm{BZ}$ monomer, this behavior was reported elsewhere [5]. The ROP of the monomers $p$ PP-BZ and $o$ PP-BZ as shown in Figure 2. The structures of $p$ PP-BZ and $o$ PP-BZ were confirmed using ${ }^{1} \mathrm{H}$ NMR spectroscopy (Figures $3 \mathrm{a}$ and $4 \mathrm{a}$ ). The signals of the aromatic protons were located at $6.75-7.9 \mathrm{ppm}$. The signals of the $\mathrm{ArCH}_{2} \mathrm{~N}$ and $\mathrm{OCH}_{2} \mathrm{~N}$ units of the oxazine rings were located at 4.5 and $5.2 \mathrm{ppm}$, respectively [34-36]. The signal of the methyl group appeared at $2.01 \mathrm{ppm}$. Figures $3 \mathrm{~b}$ and $4 \mathrm{~b}$ present the ${ }^{13} \mathrm{C}$ NMR spectra of the monomers $p$ PP-BZ and $o$ PP-BZ. The signals of the carbon nuclei of the $\mathrm{ArCH}_{2} \mathrm{~N}$ and $\mathrm{OCH}_{2} \mathrm{~N}$ units of the oxazine rings were located near 50 and $80 \mathrm{ppm}$, respectively. The signals for the symmetric $\mathrm{C}=\mathrm{O}$ groups of the imide moieties were centered at $166.55 \mathrm{ppm}$. The signals of the aromatic rings appeared in the range of 119-150 ppm.

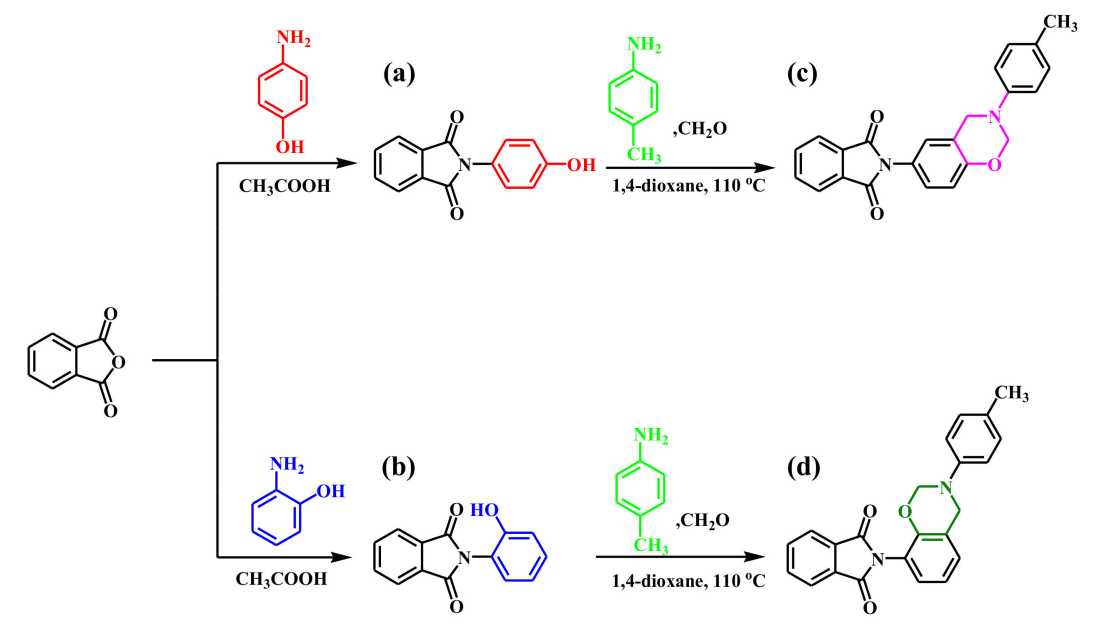

Figure 1. Synthesis of (a) $p \mathrm{PP},(\mathbf{b}) o \mathrm{PP},(\mathbf{c}) p \mathrm{PP}-\mathrm{BZ}$, and (d) $o \mathrm{PP}-\mathrm{BZ}$. 
(a)

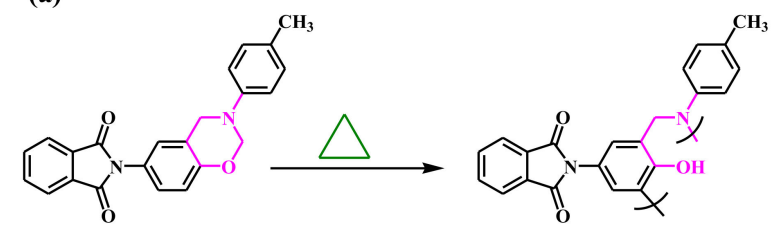

(b)

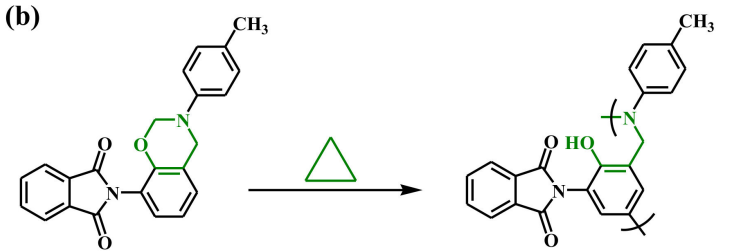

Figure 2. ROP of (a) $p \mathrm{PP}-\mathrm{BZ}$ and (b) $o \mathrm{PP}-\mathrm{BZ}$.

(a)

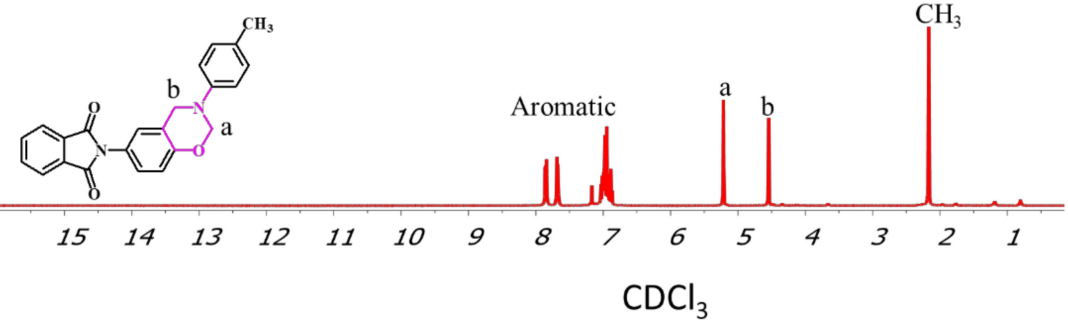

(b)

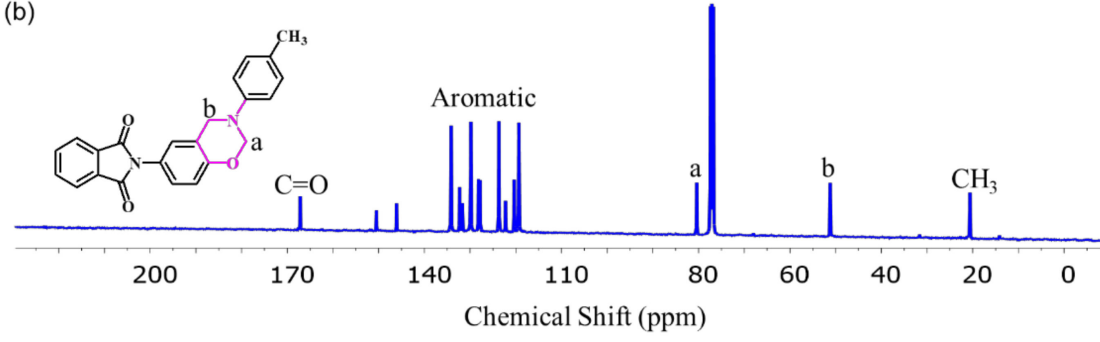

Figure 3. (a) ${ }^{1} \mathrm{H}$ and (b) ${ }^{13} \mathrm{C}$ NMR spectra of $p$ PP-BZ.

(a)

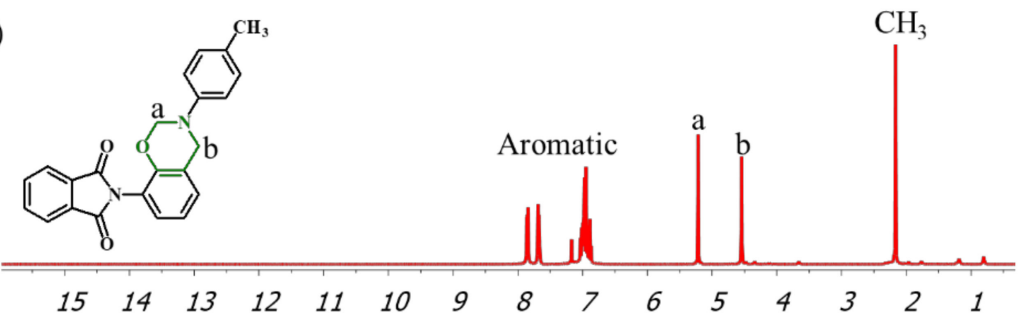

(b)

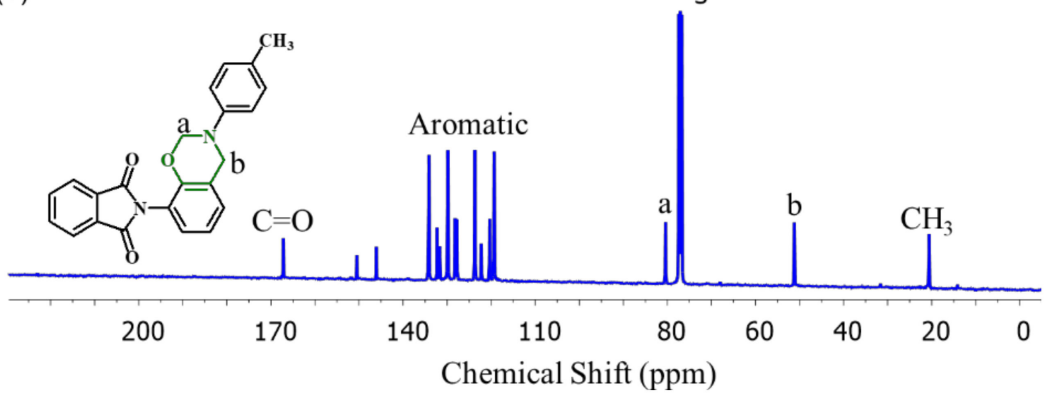

Figure 4. (a) ${ }^{1} \mathrm{H}$ and (b) ${ }^{13} \mathrm{C}$ NMR spectra of $o$ PP-BZ. 
Furthermore, the structures of $p$ PP-BZ and $o$ PP-BZ monomers were confirmed using FTIR spectroscopy (Figures 5 and 6). The signals at 1778 and $1717 \mathrm{~cm}^{-1}$ for $p$ PP-BZ and at 1772 and $1720 \mathrm{~cm}^{-1}$ for $o$ PP-BZ represent asymmetric and symmetric stretching, respectively, of the $\mathrm{C}-\mathrm{C}(=\mathrm{O})-\mathrm{C}$ units of their imide groups [37]. For both benzoxazine monomers, the signals at 1227 and $1209 \mathrm{~cm}^{-1}$ represent the aromatic ether units (C-O-C asymmetric stretching), while the bands at 925 and $929 \mathrm{~cm}^{-1}$ represent out-of-plane bending of the benzene rings attached to oxazine rings [38]. All these results suggested that we successfully synthesized benzoxazine monomers $p$ PP-BZ and $o$ PP-BZ.

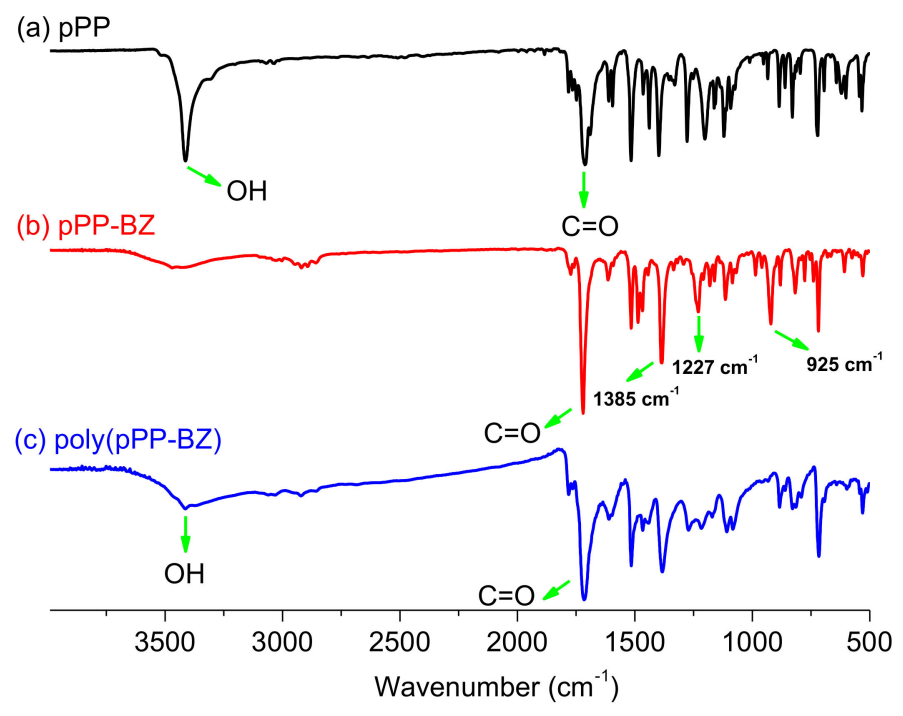

Figure 5. FTIR spectra of (a) $p$ PP, (b) $p$ PP-BZ, and (c) poly( $p$ PP-BZ).

(a) o-PP

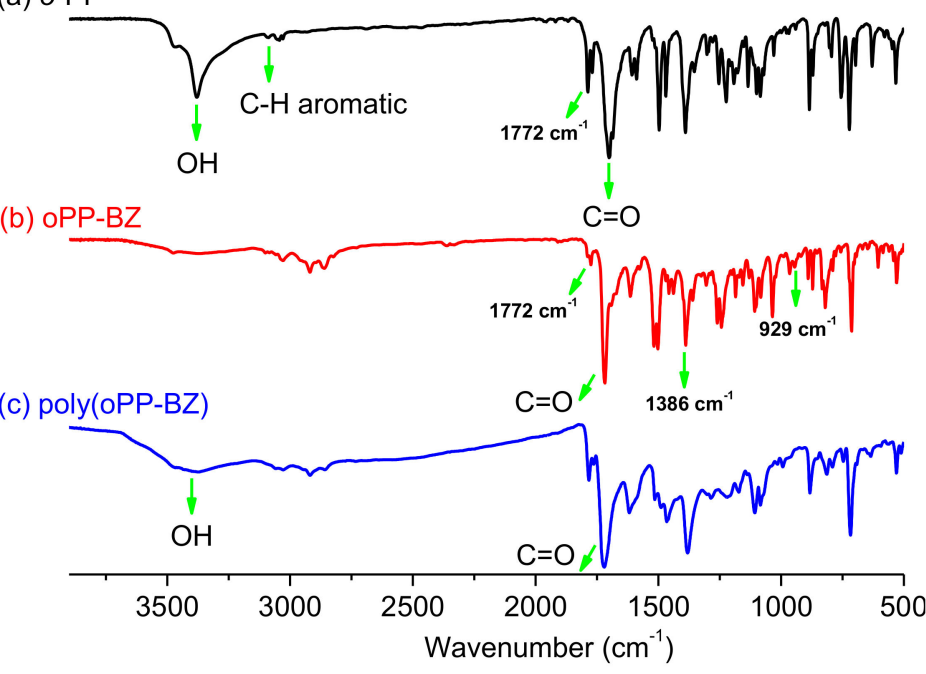

Figure 6. FTIR spectra of (a) $o$ PP, (b) $o$ PP-BZ, and (c) poly(oPP-BZ).

We used DSC and FTIR spectroscopy to study the ROP of the monomers $p$ PP-BZ and $o$ PP-BZ (Figure 2). Figures $7 \mathrm{a}$ and $8 \mathrm{~b}$ display DSC thermograms of $p$ PP-BZ and $o$ PP-BZ, respectively: uncured and after curing at 150,180 , and $210^{\circ} \mathrm{C}$. For the uncured $p$ PP-BZ, the endothermic peak (melting point), exothermic peak (ROP), and heat of polymerization were $175^{\circ} \mathrm{C}, 234{ }^{\circ} \mathrm{C}$, and $49.42 \mathrm{~J} \cdot \mathrm{g}^{-1}$, respectively. The sharp and high melting peak indicated good purity for the phthalimide-modified benzoxazine monomer and its high rigidity (cf. other traditional benzoxazine monomers) as a result of the attachment of the imide group to the aromatic structure. For the uncured $o$ PP-BZ, the endothermic peak was not evident because it partially overlapped the exothermic peak, which had shifted to 
$205^{\circ} \mathrm{C}$ [5]. In this study, the exothermic peaks appeared at temperatures lower than those of some other reported imide-functionalized benzoxazines that have been used in the synthesis of high-performance materials [39]. The exothermic peaks of $p$ PP-BZ and oPP-BZ disappeared completely after curing at $180{ }^{\circ} \mathrm{C}$, indicating their complete ROP. Furthermore, the glass transition temperatures $\left(T_{\mathrm{g}}\right)$ of poly $\left(p\right.$ PP-BZ) and poly $\left(o\right.$ PP-BZ) after curing at 180 and $210^{\circ} \mathrm{C}$ were obtained as mean values of the three repeated measurements and the standard deviation (SD) was calculated in Table 1. As shown in Table 1 , the $T_{\mathrm{g}}$ values of poly $\left(p\right.$ PP-BZ) and poly $\left(o\right.$ PP-BZ) after curing at 180 and $210{ }^{\circ} \mathrm{C}$ were 214 , $219^{\circ} \mathrm{C}$, and 212 and $217^{\circ} \mathrm{C}$, respectively. Thus, our new PBZs had values of $T_{\mathrm{g}}$ higher than those previously reported for the cross-linked material NDOPoda Bz $\left(192\right.$ and $205^{\circ} \mathrm{C}$ after curing at 180 and $210{ }^{\circ} \mathrm{C}$, respectively) [40]. We attribute the high values of $T_{\mathrm{g}}$ of our polymers to their high densities of intra- and intermolecular hydrogen bonds between the phenolic $\mathrm{OH}$ groups and the $\mathrm{N}$ atoms in the Mannich bridges or the $\mathrm{C}=\mathrm{O}$ groups in the imide structures.
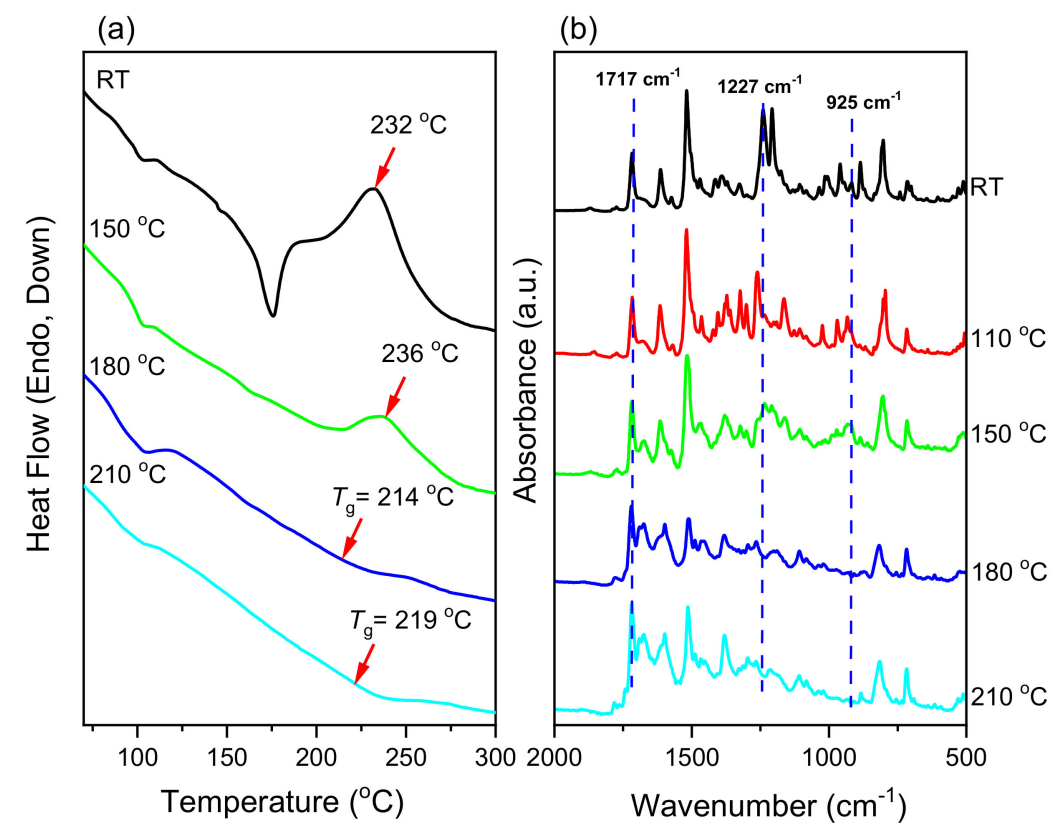

Figure 7. (a) DSC thermograms and (b) FTIR spectra of $p$ PP-BZ before and after thermal treatment.

We also used FTIR spectroscopy to study the thermal ROP behavior of the monomers $p$ PP-BZ and $o$ PP-BZ (Figures $7 \mathrm{~b}$ and $8 \mathrm{~b}$, respectively). For $p$ PP-BZ and $o$ PP-BZ, bands appeared at 1227 and $1209 \mathrm{~cm}^{-1}$, respectively, for C-O-C antisymmetric stretching and at 925 and $929 \mathrm{~cm}^{-1}$, respectively, for out-of-plane bending of the benzene rings attached to oxazine rings. After curing at temperatures from 180 to $210^{\circ} \mathrm{C}$, the signals representing the oxazine rings of the monomers disappeared progressively and broad bands representing phenolic $\mathrm{OH}$ groups appeared in the range $3500-3300 \mathrm{~cm}^{-1}$, consistent with the formation of poly( $p$ PP-BZ) and poly(oPP-BZ) (Figures $7 \mathrm{~b}$ and $8 \mathrm{~b}$ ). 

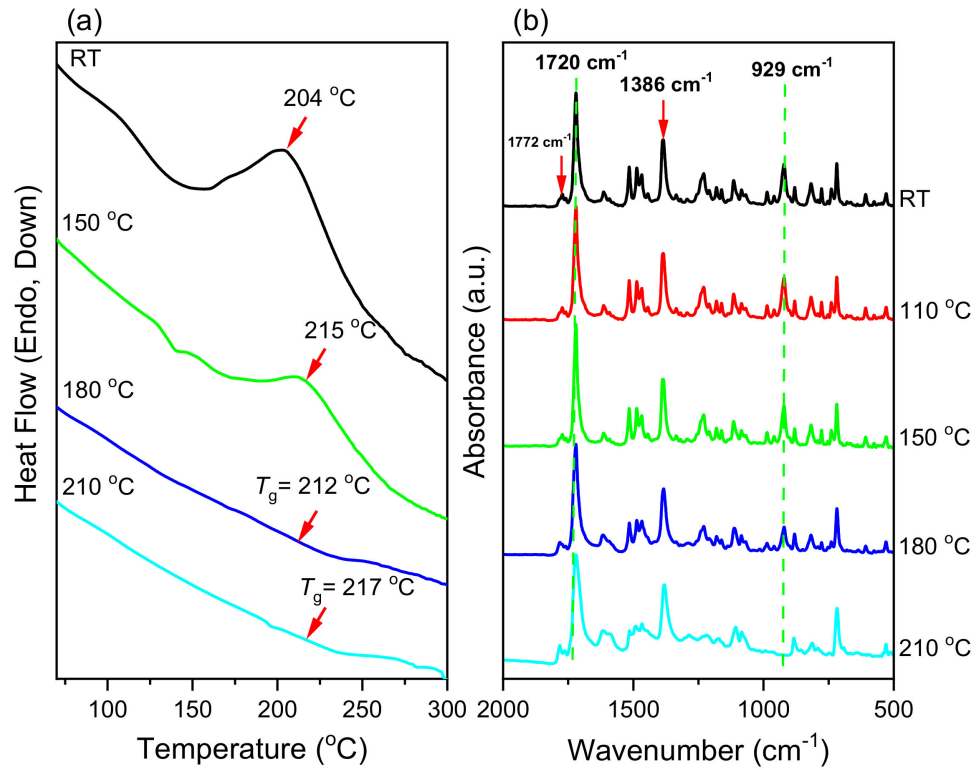

Figure 8. (a) DSC thermograms and (b) FTIR spectra of $o$ PP-BZ before and after thermal treatment.

Table 1. DSC and TGA results for $p$ PP-BZ and $o$ PP-BZ before and after thermal treatment.

\begin{tabular}{|c|c|c|c|c|c|}
\hline Samples & Curing Temperature $\left({ }^{\circ} \mathrm{C}\right)$ & $T_{\mathrm{d} 5}\left({ }^{\circ} \mathrm{C}\right)$ & $T_{\mathrm{d} 10}\left({ }^{\circ} \mathrm{C}\right)$ & Char Yield (\%) & $T_{\mathrm{g}} / \mathrm{DSC}\left({ }^{\circ} \mathrm{C}\right)$ \\
\hline \multirow{4}{*}{ pPP-BZ } & $\mathrm{RT}$ & 179 & 215 & 13 & - \\
\hline & 150 & 244 & 286 & 26 & - \\
\hline & 180 & 259 & 286 & 33 & $214 \pm 1$ \\
\hline & 210 & 296 & 321 & 37 & $219 \pm 1$ \\
\hline \multirow{4}{*}{ oPP-BZ } & $\mathrm{RT}$ & 219 & 245 & 40 & - \\
\hline & 150 & 234 & 256 & 42 & - \\
\hline & 180 & 255 & 279 & 44 & $212 \pm 1$ \\
\hline & 210 & 264 & 289 & 48 & $217 \pm 1$ \\
\hline
\end{tabular}

We used TGA to investigate the thermal stability of the uncured $p$ PP-BZ and $o$ PP-BZ and their corresponding polymers obtained after curing at 150,180 , and $210{ }^{\circ} \mathrm{C}$ (Figure 9a,b, Table 1). We considered the temperatures of 5 and $10 \%$ weight loss ( $T_{\mathrm{d} 5}$ and $T_{\mathrm{d} 10}$, respectively) to characterize the thermal stabilities of the monomers and corresponding PBZs. The values of $T_{\mathrm{d} 5}$ and $T_{\mathrm{d} 10}$ and the char yields increased progressively upon increasing the curing temperature, due to the formation of highly cross-linked thermosets. For poly ( $p$ PP-BZ) after curing at $210{ }^{\circ} \mathrm{C}$, the values of $T_{\mathrm{d} 5}$ and $T_{\mathrm{d} 10}$ and the char yield at $800^{\circ} \mathrm{C}$ were 296 and $321^{\circ} \mathrm{C}$ and $37 \mathrm{wt} . \%$, respectively; for poly(oPP-BZ) after curing at $210^{\circ} \mathrm{C}$, these values were 264 and $281^{\circ} \mathrm{C}$, and $48 \mathrm{wt}$ \% respectively. Thus, the thermal stabilities of our new polymers poly $(p \mathrm{PP}-\mathrm{BZ})$ and poly $(o \mathrm{PP}-\mathrm{BZ})$ cured at $210^{\circ} \mathrm{C}$ were higher than that of $\mathrm{Pp}-\mathrm{IB}$, a monofunctional benzoxazine featuring an imide group ( 286 and $322^{\circ} \mathrm{C}$ and $32 \mathrm{wt} \%$, respectively) [41]. The thermal stability and char yields of poly(oPP-BZ) (formed from the ortho-monomer) were much higher than those of poly ( $p$ PP-BZ) (formed from the para-monomer), because of a higher degree of cross-linking and a higher density of intramolecular hydrogen bonds. 
(a)

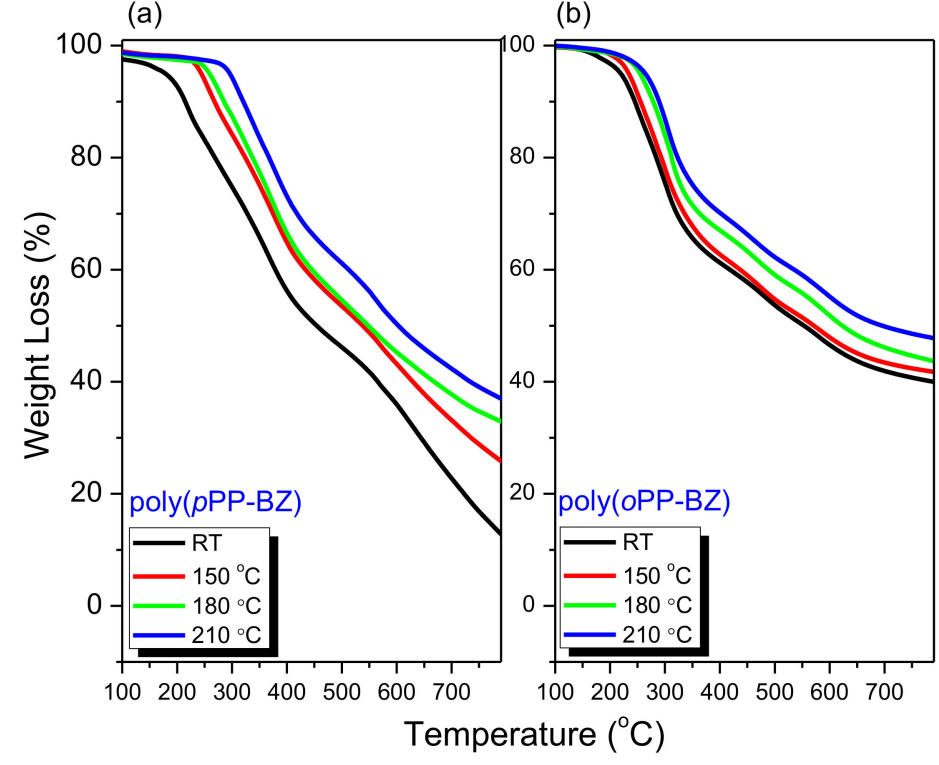

Figure 9. TGA thermograms of (a) $p \mathrm{PP}-\mathrm{BZ}$ and (b) $o$ PP-BZ before and after thermal treatment.

\subsection{Surface Properties of MS Coated with poly(pPP-BZ) and poly(oPP-BZ)}

The surface hydrophobicity and adhesion of a polymer coating are characteristics that affect its long-term use and corrosion resistance performance [32]. Figure 10a,b displays the surface hydrophobicities of the uncoated MS and of the MS coated with poly $(p \text { PP-BZ })_{150}$, poly $(p \text { PP-BZ })_{180}$, $\operatorname{poly}(p \text { PP-BZ })_{210}$, poly $(o \text { PP-BZ })_{150}$, poly $(o \text { PP-BZ })_{180}$, and poly $(o \text { PP-BZ })_{210}$ before exposure to a corrosive medium, as determined using WCA measurements. The results as mean values and their SD are summarized in Table S1. The uncoated MS had a hydrophilic surface with a WCA of $70^{\circ} \pm 1^{\circ}$, suggesting that it would readily be attacked by corrosive agents. The curing temperature had a slight influence on the WCA of the prepared coating samples, but all of the coated samples had hydrophobic surfaces (WCAs: $>90^{\circ}$ ), which we attribute to the low surface free energies of PBZ coatings [25,42-44]. Hydrophobic phthalimide-functionalized PBZ coatings have been demonstrated previously to decrease the wettability of corrosive media and provide strong barrier effects [34]. Among our tested materials, the poly $(p \text { PP-BZ })_{180}$ and poly $(o \text { PP-BZ })_{180}$ coatings provided the highest WCAs of $102^{\circ}$ and $98^{\circ}$, respectively, because of their high degrees of hydrogen bonding and high densities of cross-linking decreasing the permeability of water to the MS surface [45]. Our poly(pPP-BZ $)_{210}$ and poly $(o \text { PP-BZ })_{210}$ coatings had slightly lower WCAs of $95^{\circ}$ and $93^{\circ}$, respectively, presumably, because their hydrogen bonding was ruptured at the high curing temperature [46]. Furthermore, we used the scalpel-cutting test to evaluate the adhesion of the poly $(p \mathrm{PP}-\mathrm{BZ})$ and poly (oPP-BZ) coatings cured on the MS surfaces at 150,180 , and $210^{\circ} \mathrm{C}$ (Figure S3) [47]. In general, the adhesion of poly( $p$ PP-BZ) on MS was better than that of poly (oPP-BZ), because of the greater degree of the hydrogen bonding between the $\mathrm{OH}$ groups of the MS surface and the cured coating. The cut edges of the poly( $p$ PP-BZ)-coated samples were smooth and free from any peeling arising from the cutting (Figure S3a-c). In contrast, in the case of the poly(oPP-BZ) coatings, some peeling occurred along with the cutting after being slicing with the scalpel (Figure S3d-f). Nevertheless, the adhesion between each coating and the MS surface was strong, presumably because of electrostatic interactions between the positively charged $\mathrm{N}$ atoms (imide and Mannich bridge) and the negatively charged MS surface as well as hydrogen bonding between the cured PBZ coating and the OH groups of the MS surface. 
(a)

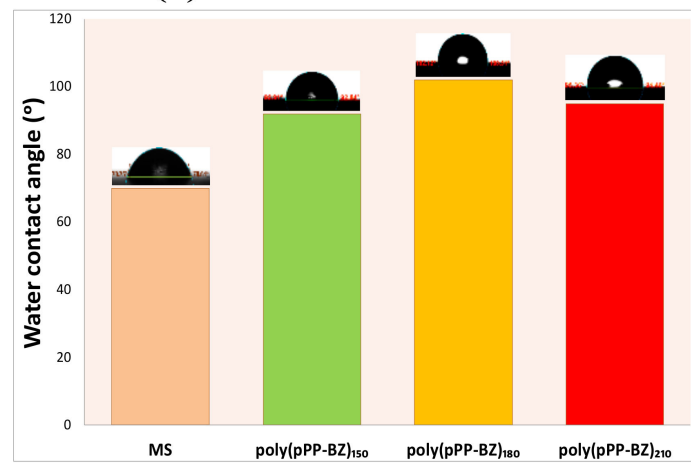

(b)

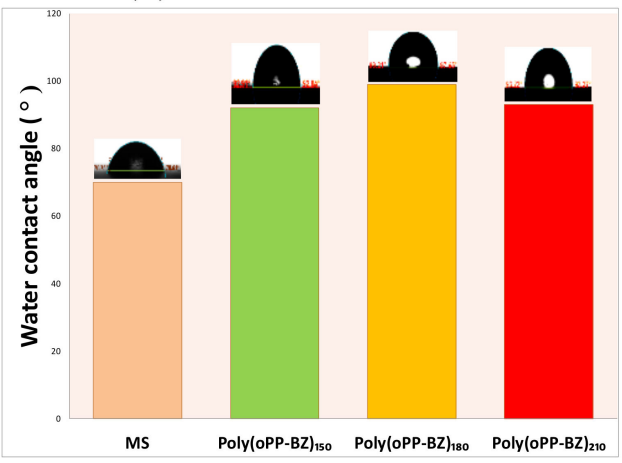

Figure 10. Water contact angles (WCAs) of (a) uncoated MS and MS coated with poly $(p \mathrm{PP}-\mathrm{BZ})_{150}$, poly $(p \text { PP-BZ })_{180}$, and poly $(p \text { PP-BZ })_{210}$ and $(\mathbf{b})$ uncoated MS and MS coated with poly $(o P P-B Z)_{150}$, poly $(\mathrm{oPP}-\mathrm{BZ})_{180}$, and poly $(\mathrm{oPP}-\mathrm{BZ})_{210}$, recorded prior to corrosion tests.

\subsection{Corrosion Resistance of MS: Uncoated and Coated with poly( $p P P-B Z)$ and poly(oPP-BZ)}

We used the open-circuit potentials $\left(E_{o c p}\right)$, thermodynamic polarization and electrochemical impedance spectroscopy (EIS) measurements to evaluate the corrosion resistance of uncoated and MS coated with poly $\left(p\right.$ PP-BZ) and poly $\left(o\right.$ PP-BZ) that cured at 150,180 , and $210{ }^{\circ} \mathrm{C}$ in a $3.5 \mathrm{wt} . \% \mathrm{NaCl}$ solution at room temperature. Figure $11 \mathrm{a}, \mathrm{b}$ represents the $E_{\mathrm{ocp}}-t$ plots of uncoated and coated MS with poly ( $p$ PP-BZ) and poly (oPP-BZ) that cured at 150,180 , and $210^{\circ} \mathrm{C}$. From this figure, it was observed that the $E_{\text {ocp }}$ value of the uncoated MS shifted to a more negative potential after immersion time from about -0.530 to $-0.718 \mathrm{~V}$. A sharp shift toward much more negative potential is due to the formation of the corrosion on the MS electrode [48]. In contrast, the $E_{\text {ocp }}$ values for poly $(p \mathrm{PP}-\mathrm{BZ})$ coatings cured at 150,180 , and $210{ }^{\circ} \mathrm{C}$ were stable with immersion time in which their start values were -0.460 , -0.520 , and $-0.530 \mathrm{~V}$ then becomes $-0.521,-0.527$, and $-0.568 \mathrm{~V}$, respectively and same behavior was observed for poly (oPP-BZ) coatings, indicating the formation of protective film on MS surface. In general, high values of $E_{\text {ocp }}$ clearly indicate that the coatings provide high corrosion resistance [49], and it was observed that the $E_{\text {ocp }}$ values of coatings that cured at $210{ }^{\circ} \mathrm{C}$ decreased a little, which can be attributed to the increase in their porosity with a higher permeability for corrosive types. We used potentiodynamic polarization to evaluate the corrosion resistance and inhibition of the uncoated and coated MS samples in $3.5 \mathrm{wt} . \% \mathrm{NaCl}$ aqueous solutions at room temperature.

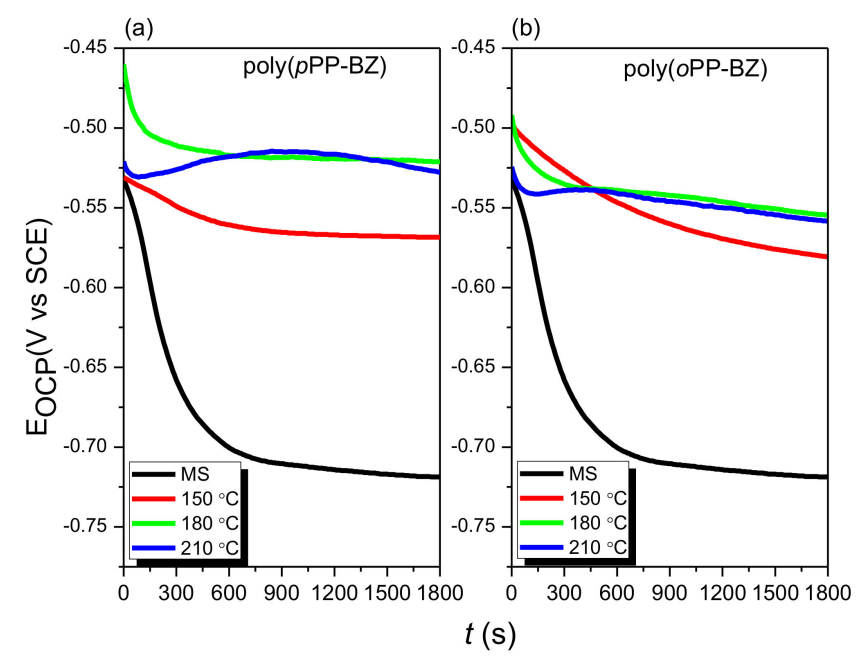

Figure 11. $E_{\mathrm{Ocp}}$-time plots of (a) uncoated MS and MS coated with poly $(p \mathrm{PP}-\mathrm{BZ})_{150}, \operatorname{poly}(p \mathrm{PP}-\mathrm{BZ})_{180}$, and poly $(p \mathrm{PP}-\mathrm{BZ})_{210}$ and $(\mathbf{b})$ uncoated MS and MS coated with poly $(o \mathrm{PP}-\mathrm{BZ})_{150}$, poly $(o \mathrm{PP}-\mathrm{BZ})_{180}$, and poly $(o \mathrm{PP}-\mathrm{BZ})_{210}$, in $3.5 \mathrm{wt} . \% \mathrm{NaCl}$. 
Figure $12 \mathrm{a}, \mathrm{b}$ presents the anodic and cathodic polarization curves of the uncoated and coated MS at various curing temperatures in $3.5 \mathrm{wt} . \% \mathrm{NaCl}$. Table 2 lists the electrochemical parameters determined from the Tafel plots: the corrosion current $\left(i_{\text {corr }}\right)$, corrosion potential $\left(E_{\text {corr }}\right)$, anodic $\left(\beta_{\mathrm{a}}\right)$, and cathodic $\left(\beta_{\mathrm{c}}\right)$ Tafel slopes, corrosion rate $(C R)$, and polarization resistance $\left(R_{\mathrm{p}}\right)[50,51]$.

(a)

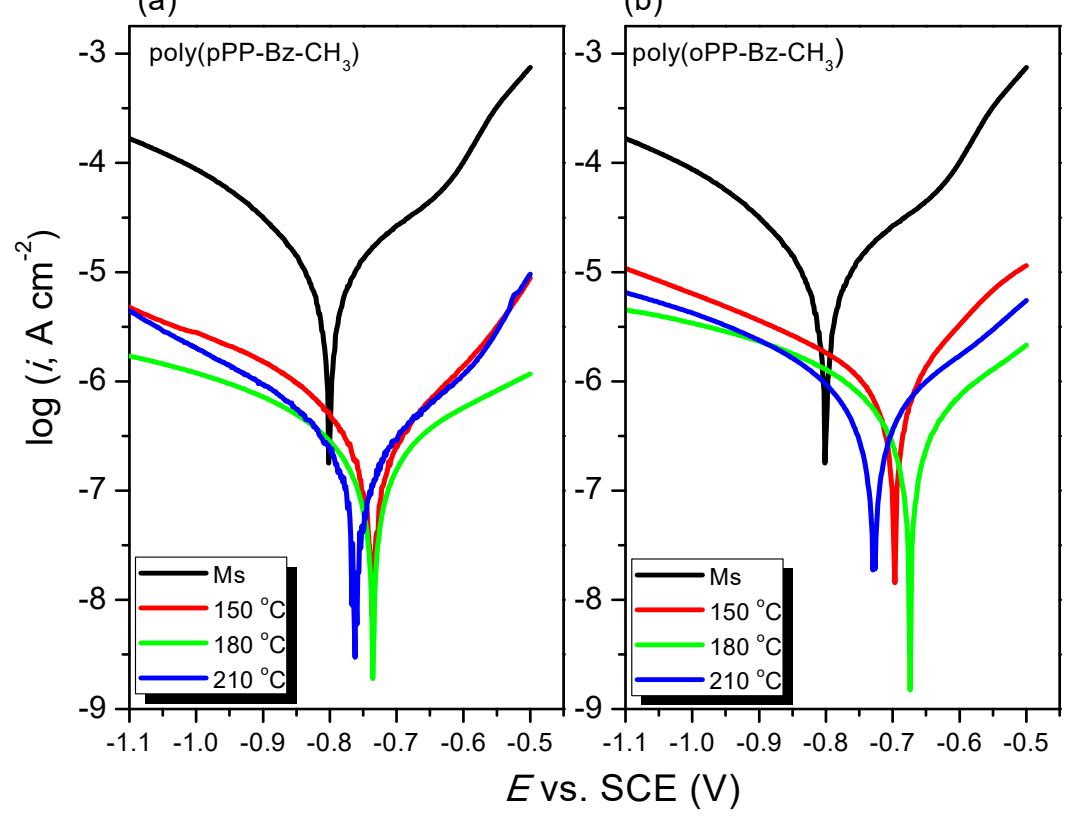

Figure 12. Tafel plots of (a) uncoated MS and MS coated with poly( $p$ PP-BZ $)_{150}$, poly( $p$ PP-BZ $)_{180}$, and poly $(p \text { PP-BZ })_{210}$ and $(\mathbf{b})$ uncoated MS and MS coated with poly $(o \text { PP-BZ })_{150}$, poly $(o \text { PP-BZ })_{180}$, and poly $(o \text { PP-BZ })_{210}$ in $3.5 \mathrm{wt.} \% \mathrm{NaCl}$.

Table 2. Potentiodynamic polarization data ( \pm standard deviation (SD)) of uncoated MS and of MS coated with poly $(p \text { PP-BZ })_{150}$, poly $(p \text { PP-BZ })_{180}$, poly $(p \text { PP-BZ })_{210}$, poly $(o P P-B Z)_{150}$, poly $(o P P-B Z)_{180}$, and poly $(o \mathrm{PP}-\mathrm{BZ})_{210}$ in $3.5 \% \mathrm{NaCl}$.

\begin{tabular}{|c|c|c|c|c|c|c|c|}
\hline Coating Samples & $\begin{array}{c}E_{\text {corr }} \\
\mathrm{mV}\end{array}$ & $\begin{array}{c}i_{\text {corr }} \\
\mu \mathrm{A} \cdot \mathrm{cm}^{-2}\end{array}$ & $\begin{array}{c}\beta_{\mathrm{a}} \\
\mathrm{mV} \cdot \mathrm{dec}^{-1}\end{array}$ & $\begin{array}{c}\beta_{\mathrm{c}} \\
\mathrm{mV} \cdot \mathrm{dec}^{-1}\end{array}$ & $\begin{array}{c}C R \\
\mu \mathrm{m} / \mathrm{Y}\end{array}$ & $\begin{array}{c}R_{\mathrm{P}} \\
\mathrm{k} \Omega \cdot \mathrm{cm}^{2}\end{array}$ & $\begin{array}{l}\eta \\
\%\end{array}$ \\
\hline uncoated MS & -803.0 & $12.44 \pm 0.09$ & $282 \pm 2$ & $-228 \pm 2$ & $145 \pm 1$ & 3.68 & - \\
\hline poly $(p \text { PP-BZ })_{150}$ & -738.3 & $0.46 \pm 0.08$ & $218 \pm 2$ & $-319 \pm 2$ & $5 \pm 1$ & 145.09 & 96.3 \\
\hline poly $(p \text { PP-BZ })_{180}$ & -737.6 & $0.24 \pm 0.05$ & $343 \pm 2$ & $-342 \pm 2$ & $3 \pm 1$ & 222.56 & 98.1 \\
\hline poly $(p \text { PP-BZ })_{210}$ & -762.7 & $0.31 \pm 0.02$ & $287 \pm 2$ & $-289 \pm 2$ & $4 \pm 1$ & 200.84 & 97.5 \\
\hline poly $(o \text { PP-BZ })_{150}$ & -699.6 & $0.91 \pm 0.07$ & $227 \pm 2$ & $-331 \pm 2$ & $11 \pm 1$ & 40.74 & 92.8 \\
\hline poly $(o \text { PP-BZ })_{180}$ & -676.6 & $0.61 \pm 0.06$ & $318 \pm 2$ & $-374 \pm 2$ & $7 \pm 1$ & 100.89 & 95.1 \\
\hline poly $(o \text { PP-BZ })_{210}$ & -730.4 & $0.79 \pm 0.03$ & $296 \pm 2$ & $-358 \pm 2$ & $9 \pm 1$ & 77.49 & 93.7 \\
\hline
\end{tabular}

The $C R$ and the value of $R_{\mathrm{p}}$ were calculated using the following equations $[52,53]$.

$$
\begin{array}{r}
R_{\mathrm{p}}=\frac{\beta_{\mathrm{a}} \times \beta_{\mathrm{c}}}{2.3 \times i_{\text {corr }}\left(\beta_{\mathrm{a}}+\beta_{\mathrm{c}}\right)} \\
C R=\frac{i_{\text {corr }} \times K \times M_{\mathrm{wt}}}{\rho \times A}
\end{array}
$$


where $i_{\text {corr }}$ is the corrosion current density, $K$ is the corrosion rate constant $\left(3.272 \mu \mathrm{m} \mathrm{Y}^{-1}\right), M_{\mathrm{wt}}$ is the molecular weight of iron, $\rho$ is the density of MS $\left(7.85 \mathrm{~g} \mathrm{~cm}^{-3}\right)$, and $A$ is the sample area $\left(\mathrm{cm}^{2}\right)$. We calculated the protection efficiency $(\eta)$ using the equation [54].

$$
\eta=\frac{i_{\text {corr }}^{\circ}-i_{\text {corr }}}{i_{\text {corr }}^{\circ}} \times 100
$$

where $i_{\text {corr }}^{\circ}$ and $i_{\text {corr }}$ are the corrosion currents of the uncoated and coated MS samples, respectively.

Figure 12a displays the Tafel plots of the uncoated MS and of the MS coated with poly $(p$ PP-BZ) and cured at 150, 180 , and $210^{\circ} \mathrm{C}$; Figure $12 \mathrm{~b}$ presents the Tafel plots of the uncoated MS and the MS coated with poly(oPP-BZ). Although the Tafel behavior of both poly( $p$ PP-BZ) and poly(oPP-BZ) was the same, the corrosion protection of poly ( $p$ PP-BZ) was superior to that of poly (oPP-BZ). The maximum corrosion protection occurred for both poly $(p \text { PP-BZ })_{180}$ and poly $(o \text { PP-BZ })_{180}$. The anodic and cathodic Tafel lines shifted toward the noble direction for the MS coated with both poly( $p$ PP-BZ) and poly (oPP-BZ), when compared with the uncoated MS. Thus, the poly( $p$ PP-BZ) and poly (oPP-BZ) coatings affected the anodic reaction mechanism, rather than the cathodic reaction mechanism. This behavior was presumably due to the compact cross-linked structures of the poly( $p$ PP-BZ) and poly(oPP-BZ) coatings curbing the anodic reaction on the MS surfaces and, thereby, inhibiting the entire corrosion process in the system [55]. The corrosion current density decreased in the presence of poly $(p$ PP-BZ) or poly(oPP-BZ) when compared with the uncoated MS surface, presumably because of the increase in the corrosion protection efficiency of the poly $(p$ PP-BZ) and poly (oPP-BZ) coatings. The corrosion protection efficiency of the MS coated with poly $(p \text { PP-BZ })_{180}$ was higher than those of the MS coated with poly $(p \text { PP-BZ })_{150}$ and poly $(p \text { PP-BZ })_{210}$; the same behavior was evident in the cases of the poly $(o P P-B Z)$ coatings. The corrosion protection efficiency of the poly $(p \mathrm{PP}-\mathrm{BZ})$ coatings on the MS surface was superior to that of the poly (oPP-BZ) coatings in $\mathrm{NaCl}$ solution, because of the poly ( $p$ PP-BZ) coatings adsorbing more strongly through greater coordinate bonding with the MS substrate [56-59]. Also, when the curing temperature of coatings increased to $210^{\circ} \mathrm{C}$, the corrosion resistance decreased a little because of decreasing hydrophobic performance [53], and also increase in volume during curing at higher temperatures might be responsible for a decrease in compactness in polybenzoxazine. Table 2 reveals that the CRs of the MS samples coated with poly( $p$ PP-BZ) and poly(oPP-BZ) were about one to two orders of magnitude lower than that of the uncoated MS, indicating that the polymers coatings adsorbed on the MS surfaces inhibited corrosion. Among our tested systems, the $C R$ reached its lowest value of $2.78 \mu \mathrm{m} \cdot \mathrm{Y}^{-1}$ for the poly $(p \text { PP-BZ })_{180}$ coating; indeed, this value is lower than that of PBA-a- $180{ }^{\circ} \mathrm{C}\left(5.75 \mu \mathrm{m} \cdot \mathrm{Y}^{-1}\right)$ [60]. In addition, the polarization resistance $\left(R_{\mathrm{p}}\right)$, defined as the resistance of the coatings toward oxidation during the application of an external potential [61], of all of our coatings on MS increased by approximately two to three orders of magnitude when compared with that of the uncoated MS. Among our systems, the values of $R_{\mathrm{p}}$ reached their maxima of $222.56 \mathrm{k} \Omega \cdot \mathrm{cm}^{2}$ for the poly $(p \text { PP-BZ })_{180}$ coating and $100.89 \mathrm{k} \Omega \cdot \mathrm{cm}^{2}$ for the poly $(o P P-B Z)_{180}$ coating. The hydrophobic phthalimide-functionalized PBZ coatings having crosslinked polymer networks could decrease the penetration permeability of electrolytes through the coatings and increase the barrier against the corrosion reaction, because of the PBZ coatings possessing low surface free energies resulting from their hydrogen-bonding networks [62,63]. In addition, we suspect that the $\pi$-electrons of the aromatic rings and the heteroatoms containing lone pairs of electrons ( $\mathrm{N}$ and $\mathrm{O}$ atoms in the oxazine ring and imide structures) assisted in the strong adsorption of the polymers onto the MS, leading to efficient protection of the metal in corrosive media [64]. EIS is a useful technique for gaining information about a coating-substrate interface because the impedance measurements are very sensitive to the corrosion mechanism [45].

Figure 13a,b displays the Nyquist plots of the uncoated MS surface and of the MS coated with poly ( $p$ PP-BZ) and poly(oPP-BZ) in 3.5 wt.\% aqueous $\mathrm{NaCl}$ at room temperature. For the MS coated with poly $(p$ PP-BZ) and poly(oPP-BZ), the semicircle was depressed and its diameter-related to the charge transfer resistance $\left(R_{\mathrm{ct}}\right)$-was greater than that in the plot of the uncoated MS. The Nyquist plots had the same shape for the uncoated MS and the coated samples that had been cured at the 
various temperatures, but with larger diameters indicating increased resistivity. These features reveal the mechanism of corrosion of the MS after coating. According to the theory of EIS, at low frequency, the loops displayed non-ideal semicircles. This variation can be explained by considering the non-ideal behavior of the double layers as a capacitor; this phenomenon was due to the frequency dispersion with relation to roughness and the non-homogeneity of the MS surface [64].

(a)

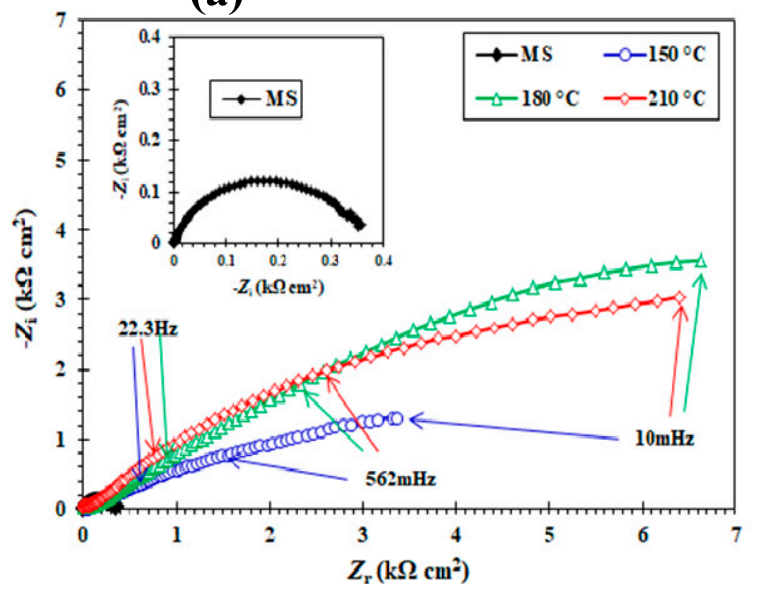

(b)

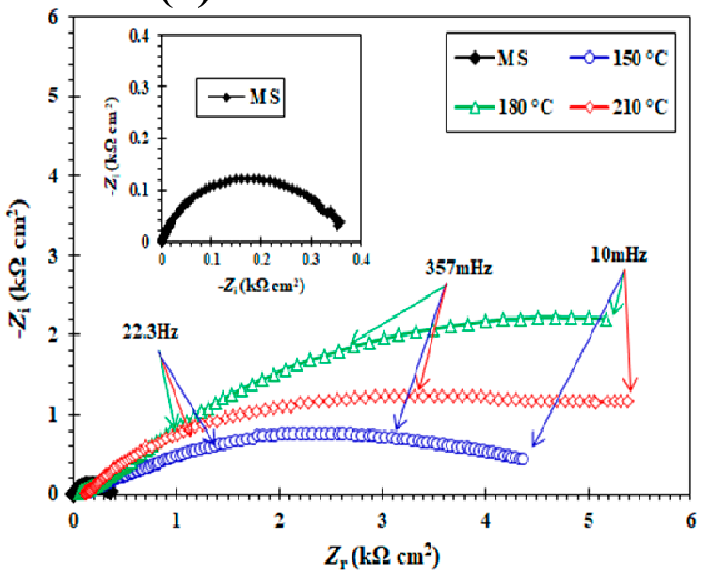

Figure 13. Nyquist plots of (a) uncoated MS and MS coated with poly( $p$ PP-BZ) $)_{150}$, poly $(p P P-B Z)_{180}$, and poly $(p P P-B Z)_{210}$ and (b) uncoated MS and MS coated with poly $(o P P-B Z)_{150}$, poly $(o P P-B Z)_{180}$, and poly $(\mathrm{oPP}-\mathrm{BZ})_{210}$ in $3.5 \mathrm{wt} . \% \mathrm{NaCl}$.

All of the EIS data were fitted using the equivalent circuit models in Figure S4a,b that describe the electrochemical system; a one-time constant model (Figure S4a) was used for the uncoated MS, and a two-time constant model Figure S4b was applied for the MS with the poly( $p$ PP-BZ) and poly $\left(o\right.$ PP-BZ) coatings. Here, $C_{\mathrm{dl}}$ is the capacitance of the double-layer capacitance (related to the electrolyte-uncoated steel substrate interface); $R_{\mathrm{p}}$ is the corrosion resistance of the coating (related to the electrolyte-coating interface), $R_{\mathrm{ct}}$ is the charge transfer resistance, and $Q_{\mathrm{dl}}$ is the double-layer capacitance (related to the electrolyte-substrate interface) [65]. The experimental data were fitted using the program ZSimpWin.

Table 3 lists the fitted EIS parameters. The estimated impedance, in this case, $Z_{\mathrm{CPE}}$, was determined as follows [64]:

$$
Z_{\mathrm{CPE}}=\frac{1}{Q_{\mathrm{dl}}(j \omega)^{n}}
$$

where the exponent $n$ is the phase shift, $j^{2}=-1, \omega=2 \pi f$.

Table 3. EIS data $( \pm \mathrm{SD})$ of uncoated MS and of MS coated with poly $(p \mathrm{PP}-\mathrm{BZ})_{150}$, $\operatorname{poly}(p \mathrm{PP}-\mathrm{BZ})_{180}$, $\operatorname{poly}(p \mathrm{PP}-\mathrm{BZ})_{210}$, poly $(o \mathrm{PP}-\mathrm{BZ})_{150}$, poly $(o \mathrm{PP}-\mathrm{BZ})_{180}$, and poly $(o \mathrm{PP}-\mathrm{BZ})_{210}$ in $3.5 \% \mathrm{NaCl}$.

\begin{tabular}{|c|c|c|c|c|c|c|c|}
\hline Coating Samples & $\underset{\left(\mu \Omega^{-1} \cdot s^{n} \cdot \mathrm{cm}^{-2}\right)}{Q c}$ & $n_{1}$ & $\begin{array}{c}R_{\mathrm{p}} \\
\left(\mathrm{k} \Omega \cdot \mathrm{cm}^{2}\right)\end{array}$ & $\begin{array}{c}Q_{\mathrm{dl}} \\
\left(\mu \Omega^{-1} \cdot \mathbf{s}^{\mathrm{n}} \cdot \mathrm{cm}^{-2}\right)\end{array}$ & $n_{2}$ & $\begin{array}{c}R_{\mathrm{ct}} \\
\left(\mathrm{k} \Omega \cdot \mathrm{cm}^{2}\right)\end{array}$ & $\begin{array}{c}\eta_{1} \\
(\%)\end{array}$ \\
\hline uncoated MS & - & - & - & $1.238 \pm 0.009$ & 0.77 & $0.35 \pm 0.08$ & - \\
\hline poly $(p \text { PP-BZ })_{150}$ & $2.7 \times 10^{-2}$ & 0.38 & $0.479 \pm 0.031$ & $0.084 \pm 0.008$ & 0.67 & $8.22 \pm 0.01$ & 95.7 \\
\hline poly $(p \text { PP-BZ })_{180}$ & $2.1 \times 10^{-3}$ & 0.71 & $0.084 \pm 0.002$ & $0.078 \pm 0.005$ & 0.50 & $29.55 \pm 0.03$ & 98.3 \\
\hline poly $(p \text { PP-BZ })_{210}$ & $1.4 \times 10^{-2}$ & 0.57 & $0.010 \pm 0.005$ & $0.081 \pm 0.004$ & 0.60 & $11.67 \pm 0.01$ & 97.0 \\
\hline poly $(o P P-B Z)_{150}$ & $6.0 \times 10^{-2}$ & 0.38 & $0.039 \pm 0.004$ & $0.118 \pm 0.006$ & 0.71 & $4.98 \pm 0.05$ & 92.9 \\
\hline poly $(o \text { PP-BZ })_{180}$ & $8.9 \times 10^{-3}$ & 0.51 & $4.381 \pm 0.055$ & $0.069 \pm 0.003$ & 0.58 & $9.84 \pm 0.04$ & 96.4 \\
\hline poly $(o \text { PP-BZ })_{210}$ & $3.9 \times 10^{-2}$ & 0.57 & $0.341 \pm 0.061$ & $0.093 \pm 0.002$ & 0.43 & $6.40 \pm 0.05$ & 94.5 \\
\hline
\end{tabular}


The double-layer capacitance $\left(C_{\mathrm{dl}}\right)$ along with a $C P E$ was estimated as reported previously [64]:

$$
C_{\mathrm{dl}}=Q_{\mathrm{dl}}\left(\omega_{\max }\right)^{n-1}
$$

where, $\omega_{\max }=2 \pi f_{\max }$ and $f_{\max }$ is the frequency at the maximal impedance-imaginary component. The MS corrosion protection efficiency $\left(\eta_{\mathrm{I}}\right)$ was obtained as follows [66]:

$$
\eta_{\mathrm{I}}=\frac{R_{\mathrm{ct}-} R_{\mathrm{ct}}^{\circ}}{R_{\mathrm{ct}}} \times 100
$$

where, $R_{\mathrm{ct}}$ and $R_{\mathrm{ct}}^{\circ}$ are the charge transfer resistances for the coated and uncoated systems, respectively.

The double-layer capacitances $\left(Q_{\mathrm{dl}}\right)$ of the poly $(p$ PP-BZ) and poly $(o$ PP-BZ) coatings were approximately two orders of magnitude lower than that of uncoated MS, indicating the adsorption of the coatings on the MS surface; the charge transfer resistance $\left(R_{\mathrm{ct}}\right)$ increased by approximately two orders of magnitude relative to that of the uncoated MS, indicating the formation of an insulating protective layer at the electrolyte-substrate interface [67]. Among our tested samples, poly( $p$ PP-BZ $)_{180}$ had the highest value of $R_{\mathrm{ct}}$ of $29.55 \mathrm{k} \Omega \cdot \mathrm{cm}^{2}$; this value is higher than that obtained previously for a P(BA-aptms) coating without epoxy $\left(8.65 \pm 3.39 \mathrm{k} \Omega \cdot \mathrm{cm}^{2}\right)$ in $3.5 \% \mathrm{NaCl}$ [25]. In contrast, the poly $(o \text { PP-BZ })_{180}$ coating had the lowest value of $Q_{\mathrm{dl}}$ of $0.069 \pm 0.03 \mu \Omega^{-1} \cdot \mathrm{s}^{\mathrm{n}} \cdot \mathrm{cm}^{2}$. A higher value of $R_{\mathrm{ct}}$ and a lower value of $Q_{\mathrm{dl}}$ always correspond to better corrosion resistance performance, because of the inhibited access of water molecules to the metal surface (through the adsorption of the organic molecules) and a less active dissolution reaction $[29,68]$. In addition, we suspect that the change in the coating resistance $\left(R_{\mathrm{p}}\right)$ was mainly due to the change in the penetration permeability of the electrolyte through the porous coating. From Table 3, it was observed, when the curing temperature of the coating increased to $210{ }^{\circ} \mathrm{C}$, its $Q_{\mathrm{dl}}$ value increases a little. This behavior can be attributed to increasing the internal stress of coating which led to the formation cracks or pores in the coating [69]. Figure $14 \mathrm{a}$, b shows the Bode and phase angles plots, and indicates that the interfacial impedance of MS coated with $p$ PP-BZ and $o$ PP-BZ increased about two orders of magnitude more than those of uncoated MS in the low-frequency range, demonstrating reinforced barrier property of $p$ PP-BZ and $o$ PP-BZ coatings on MS. The Phase angle is also significant to detect the performance of the coating surface. Two-time constants at different frequencies were observed for each coated MS samples cured at 150,180 , and $210^{\circ} \mathrm{C}$. Generally, EIS results for each the tested MS coated were well consistent with the results in Tafel curves. The corrosion resistance performance of organic coatings depends greatly on their surface morphology. Figure S5 shows the SEM surface images of uncoated and MS coated with poly ( $p$ PP-BZ $)_{180}$. The surface of coated MS with poly( $p$ PP-BZ $)_{180}$ is uniform, smooth, and not affected by salt solution attack (Figure S5c). On the other hand, the same morphology was not observed for uncoated MS surface (Figure S5b). The scratches on the surface of MS are due to the pre-polishing using the emery papers (Figure S5a). 
(a)

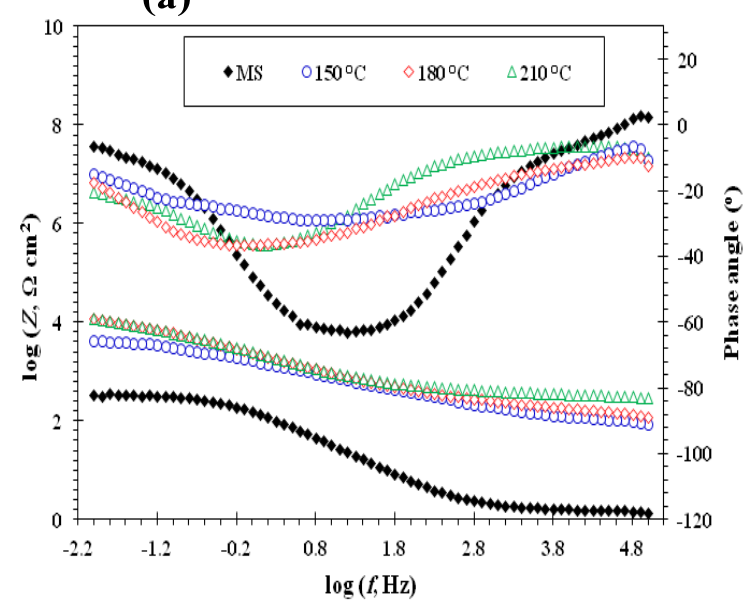

(b)

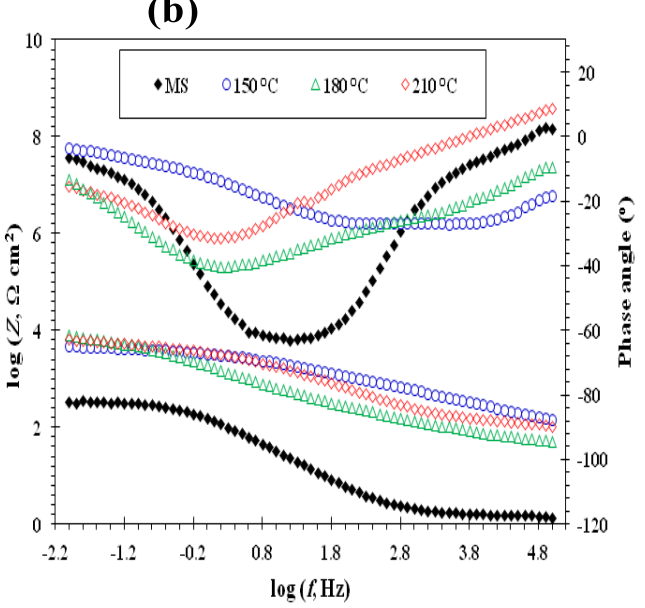

Figure 14. Bode and phase angle plots of (a) uncoated MS and MS coated with poly $(p P P-B Z)_{150}$, poly $(p \text { PP-BZ })_{180}$, and poly $(p \text { PP-BZ })_{210}$ and $(\mathbf{b})$ uncoated MS and MS coated with poly $(o \text { PP-BZ })_{150}$, poly $(o \mathrm{PP}-\mathrm{BZ})_{180}$, and poly $(o \mathrm{PP}-\mathrm{BZ})_{210}$ in $3.5 \mathrm{wt} . \% \mathrm{NaCl}$ solution.

\section{Conclusions}

We have synthesized the phthalimide-functionalized benzoxazine monomers $p$ PP-BZ and oPP-BZ from reactions of $p \mathrm{PP}$ and $o \mathrm{PP}$, respectively, with $p$-toluidine and paraformaldehyde in 1,4-dioxane. Their corresponding polymers obtained after thermal curing had high values of $T_{\mathrm{g}}\left(>212{ }^{\circ} \mathrm{C}\right)$, as determined through DSC analysis. The poly(oPP-BZ) series had thermal stabilities and char yields higher than those of the poly ( $p$ PP-BZ) series, because of the greater crosslinking density and degree of intramolecular hydrogen bonding in the former after ring-opening of the oxazine units. The corrosion resistance of MS coated by poly ( $p$ PP-BZ) coatings in a $3.5 \mathrm{wt} . \% \mathrm{NaCl}$ solution was better than the MS coated by poly(oPP-BZ) coatings. This was due to the strongly adsorbing of poly( $p$ PP-BZ) coatings through coordination interaction with MS surfaces. Furthermore, the corrosion resistance of the prepared hydrophobic coatings on $\mathrm{MS}$ in $3.5 \mathrm{wt} . \% \mathrm{NaCl}$ was enhanced significantly after curing at temperatures from 150 to $210{ }^{\circ} \mathrm{C}$; the corrosion rate reached its lowest value of $3 \mu \mathrm{m} \cdot \mathrm{Y}^{-1}$ for the poly $\left(p\right.$ PP-BZ) 180 coating (cf. $145.40 \mu \mathrm{m} \cdot \mathrm{Y}^{-1}$ for the uncoated MS). Finally, incorporating imide structures into benzoxazine coatings appears to be a good strategy for affording high-performance corrosion resistance.

Supplementary Materials: The following are available online at http://www.mdpi.com/2079-6412/10/11/1114/s1. Figure S1: ${ }^{1} \mathrm{H}$ NMR spectrum of $p$-PP. Figure S2: ${ }^{1} \mathrm{H}-\mathrm{NMR}$ spectrum of $o$-PP. Figure S3: photographs of the scalpel-cut of MS coated with (a) poly $\left(p\right.$ PP-BZ) 150 , (b) poly $(p \text { PP-BZ })_{180}$ and (c) poly $\left(p\right.$ PP-BZ) 210 , (d) poly $(o P P-B Z)_{150}$, (e) poly (oPP-BZ) 180 and (f) poly (oPP-BZ) 210 . Figure S4: Equivalent circuit models with (a) one time constant (uncoated MS) and (b) two-time constants (coated MS) used to fit the impedance data. Table S1: Water contact angles (WCAs) results (mean \pm standard deviation) of uncoated MS and MS coated by $p$ PP-BZ and $o$ PP-BZ at various curing temperatures and recorded prior to corrosion tests. Figure S5: SEM surface images of (a) polished MS, (b) uncoated MS after immersing in a $3.5 \mathrm{wt}$.\% aqueous solution of $\mathrm{NaCl}$, and (c) MS coated with poly $(\mathrm{pPP}-\mathrm{BZ})_{180}$.

Author Contributions: K.I.A., supervision; A.M., methodology, investigation, formal analysis and data curation; M.A.H., formal analysis; N.S.A.-M., formal analysis; S.-W.K., formal analysis; M.G.M., methodology, formal analysis, data curation, investigation, writing - original draft preparation and supervision. All authors have read and agreed to the published version of the manuscript.

Funding: This study was supported financially by the Science and Technology Development Fund (STDF, Egypt) (call 6/STDF Basic and Applied Research Grants (STDF-BARG)/Basic and Applied Research Grants) Project ID: 28930.

Conflicts of Interest: The authors declare no conflict of interest. 


\section{References}

1. Lyu, Y.; Rachita, E.; Pogharian, N.; Froimowiczc, P.; Ishida, H. Electronic effects of asymmetric and meta-alkoxy substituents on the polymerization behavior of bis-benzoxazines. Polym. Chem. 2020, 11, 800-809. [CrossRef]

2. Mohamed, M.G.; Kuo, S.W. Crown Ether-Functionalized Polybenzoxazine for Metal Ion Adsorption. Macromolecules 2020, 53, 2420-2429. [CrossRef]

3. Ma, C.; Han, L.; Ma, Z.; Ishida, H. Preparation, and characterization of carbon fiber reinforced polybenzoxazine and polybenzoxazole composites from the same precursor: Use of a smart, ortho-substituted and amide-co-imide functional matrix. Compos. Sci. Technol. 2020, 195, 108205. [CrossRef]

4. Bai, L.; Ge, Y.; Bai, L. Boron and Nitrogen Co-Doped Porous Carbons Synthesized from Polybenzoxazines for High-Performance Supercapacitors. Coatings 2019, 9, 657. [CrossRef]

5. Zhang, K.; Liu, Y.; Han, L.; Wang, J.; Ishida, H. Synthesis and thermally induced structural transformation of phthalimide and nitrile-functionalized benzoxazine: Toward smart ortho-benzoxazine chemistry for low flammability thermosets. RSC Adv. 2019, 9, 1526-1535. [CrossRef]

6. Zhang, X.; Mohamed, M.G.; Xin, Z.; Kuo, S.W. A tetraphenylethylene-functionalized benzoxazine and copper (II) acetylacetonate form a high-performance polybenzoxazine. Polymer 2020, 201, 122552. [CrossRef]

7. Mohamed, M.G.; Hsu, K.C.; Kuo, S.W. Bifunctional polybenzoxazine nanocomposites containing photo-crosslinkable coumarin units and pyrene units capable of dispersing single-walled carbon nanotubes. Polym. Chem. 2015, 6, 2423-2433. [CrossRef]

8. Zhang, K.; Ishida, H. Polymerization of an AB-Type Benzoxazine Monomer toward Different Polybenzoxazine Networks: When Diels-Alder Reaction Meets Benzoxazine Chemistry in a Single-Component Resin. Macromolecules 2019, 52, 7386-7395. [CrossRef]

9. Mohamed, M.G.; Kuo, S.W. Functional Silica and Carbon Nanocomposites Based on Polybenzoxazines. Macromol. Chem. Phys. 2019, 220, 1800306-1800318. [CrossRef]

10. Dai, J.; Yang, S.; Teng, N.; Liu, Y.; Liu, X.; Zhu, J.; Zhao, J. Synthesis of Eugenol-Based Silicon-Containing Benzoxazines and Their Applications as Bio-Based Organic Coatings. Coatings 2018, 8, 88. [CrossRef]

11. Arslan, M.; Kiskan, B.; Yagci, Y. Benzoxazine-Based Thermoset with Autonomous Self-Healing and Shape Recovery. Macromolecules 2018, 5, 10095-10103. [CrossRef]

12. Zhang, K.; Liu, Y.; Evans, C.J.; Yang, S. Easily Processable Thermosets with Outstanding Performance via Smart Twisted Small-Molecule Benzoxazines. Macromol. Rapid. Comm. 2020, 41, 1900625. [CrossRef] [PubMed]

13. Akkus, B.; Kiskan, B.; Yagci, Y. Combining polybenzoxazines and polybutadienes via simultaneous inverse and direct vulcanization for flexible and recyclable thermosets by polysulfide dynamic bonding. Polym. Chem. 2019, 10, 5743-5750. [CrossRef]

14. Liu, Y.; Yin, R.; Yu, X.; Zhang, K. Modification of solventless synthesized benzoxazine resin by phthalonitrile group: An effective approach for enhancing thermal stability of polybenzoxazines. Macromol. Chem. Phys. 2018, 220, 1800291-1800297. [CrossRef]

15. Zhang, K.; Yu, X. Catalyst-Free and Low-Temperature Terpolymerization in a Single-Component Benzoxazine Resin Containing Both Norbornene and Acetylene Functionalities. Macromolecules 2018, 51, $6524-6533$. [CrossRef]

16. Zhang, T.; Bonnaud, L.; Raquez, T.M.; Poorteman, M.; Olivier, M.; Dubois, P. Cerium Salts: An Efficient Curing Catalyst for Benzoxazine Based Coatings. Polymers 2020, 12, 415. [CrossRef]

17. Samy, M.M.; Mohamed, M.G.; Kuo, S.W. Pyrene-functionalized tetraphenylethylene polybenzoxazine for dispersing single-walled carbon nanotubes and energy storage. Compos. Sci. Technol. 2020, 199, 108360. [CrossRef]

18. Mohamed, M.G.; Ebrahium, S.M.; Hammam, A.S.; Kuo, S.W.; Aly, K.I. Enhanced $\mathrm{CO}_{2}$ capture in nitrogen-enriched microporous carbons derived from Polybenzoxazines containing azobenzene and carboxylic acid units. J. Polym. Res. 2020, 27, 197. [CrossRef]

19. Mohamed, M.G.; Kuo, S.W.; Mahdy, A.; Ghayd, I.M.; Aly, K.I. Bisbenzylidene cyclopentanone and cyclohexanone-functionalized polybenzoxazine nanocomposites: Synthesis, characterization, and use for corrosion protection on mild steel. Mater. Today Commun. 2020, 25, 101418. [CrossRef]

20. Lin, R.C.; Mohamed, M.G.; Kuo, S.W. Benzoxazine/Triphenylamine-Based Dendrimers Prepared through Facile One-Pot Mannich Condensations. Macromol. Rapid Commun. 2017, 38, 1700251. [CrossRef] 
21. Vanherck, K.; Koeckelberghs, G.; Vankelecom, I.F. Crosslinking polyimides for membrane applications: A review. Prog. Polym. Sci. 2013, 38, 874-896. [CrossRef]

22. Mohamed, M.G.; Kuo, S.W. Functional polyimide/polyhedral oligomeric silsesquioxane nanocomposites. Polymers 2019, 11, 26. [CrossRef] [PubMed]

23. Yao, B.; Yan, X.; Ding, Y.; Lu, Z.; Dong, D.; Ishida, H.; Zhu, L. Synthesis of sulfonic acid-containing polybenzoxazine for proton ex proton exchange membrane in direct methanol fuel cells. Macromolecules 2014, 47, 1039-1045. [CrossRef]

24. Takeichi, T.; Guo, Y.; Rimdusit, S. Performance improvement of polybenzoxazine by alloying with polyimide: Effect of preparation method on the properties. Polymer 2005, 46, 4909-4916. [CrossRef]

25. Zhou, C.; Lin, J.; Lu, X.; Xin, Z. Enhanced corrosion resistance of polybenzoxazine coatings by epoxy incorporation. RSC Adv. 2016, 6, 28428-28434. [CrossRef]

26. Van Westing, E.P.M.; Ferrari, G.M.; De Wit, J.H.W. The determination of coating performance with impedance measurements-I. Coating polymer properties. Corros. Sci. 1993, 34, 1511-1530. [CrossRef]

27. Krishnan, S.; Arumugam, H.; Kuppan, C.; Goswami, A.; Chavali, M.; Muthukaruppan, A. Silane-functionalized polybenzoxazines: A superior corrosion resistant coating for steel plates. Mater. Corros. 2017, 68, 1343-1354. [CrossRef]

28. Zhang, R.; Lu, X.; Lou, C.; Zhou, C.; Xin, Z. Preparation of diamine-based polybenzoxazine coating for corrosion protection on mild steel. J. Polym. Res. 2019, 26, 29. [CrossRef]

29. Li, S.; Zhao, C.; Gou, H.; Li, H.; Li, Y.; Xiang, D. Synthesis and characterization of aniline-dimer-based electroactive benzoxazine and its polymer. RSC Adv. 2017, 7, 55796-55806. [CrossRef]

30. Li, S.; Zhao, C.; Wang, Y.; Li, H.; Li, Y. Synthesis and electrochemical properties of electroactive aniline-dimer-based benzoxazines for advanced corrosion-resistant coatings. J. Mater. Sci. 2018, 53, 7344-7356. [CrossRef]

31. Lu, X.; Liu, Y.; Zhang, W.; Zhang, X.; Zhou, C.; Xin, Z. Crosslinked main-chain-type polybenzoxazine coatings for corrosion protection of mild steel. J. Coat. Technol. Res. 2017, 14, 937-944. [CrossRef]

32. Hamak, K.F. Synthetic of Phthalimides via the reaction of phthalic anhydride with amines and evaluating of its biological and anticorrosion activity. Int. J. Chem. Tech. Res. 2014, 6, 324-333.

33. Hegazy, M.A. A novel Schiff base-based cationic gemini surfactants: Synthesis and effect on corrosion inhibition of carbon steel in hydrochloric acid solution. Corros. Sci. 2009, 51, 2610-2618. [CrossRef]

34. Mohamed, M.G.; Tsai, M.Y.; Su, W.C.; EL-Mahdy, A.F.M.; Wang, C.F.; Huang, C.F.; Dai, L.; Chen, T.; Kuo, S.W. Nitrogen-Doped microporous carbons derived from azobenzene and nitrile-functionalized polybenzoxazines for $\mathrm{CO}_{2}$ uptake. Mater. Today Commun. 2020, 24, 101111. [CrossRef]

35. Samy, M.M.; Mohamed, M.G.; Kuo, S.W. Directly synthesized nitrogen-and-oxygen-doped microporous carbons derived from a bio-derived polybenzoxazine exhibiting high-performance supercapacitance and $\mathrm{CO}_{2}$ uptake. Eur. Polym. J. 2020, 138, 109954. [CrossRef]

36. Aly, K.I.; Mohamed, M.G.; Younis, O.; Mahross, M.H.; Hakim, M.A.; Sayed, M.M. Salicylaldehyde azine-functionalized polybenzoxazine: Synthesis, characterization, and its nanocomposites as coatings for inhibiting the mild steel corrosion. Prog. Org. Coat. 2020, 138, 105385. [CrossRef]

37. Wang, H.; Liu, S.; Chung, T.S.; Chen, H.; Jean, Y.C.; Pramoda, K.P. The evolution of poly (hydroxyamide amic acid) to poly (benzoxazole) via stepwise thermal cyclization: Structural changes and gas transport properties. Polymer 2011, 52, 5127-5138. [CrossRef]

38. Chen, W.C.; Kuo, S.W. Ortho-Imide and Allyl Groups Effect on Highly Thermally Stable Polybenzoxazine/Double-Decker-Shaped Polyhedral Silsesquioxane Hybrids. Macromolecules 2018, 51, 9602-9612. [CrossRef]

39. Zhang, K.; Ishida, H. An anomalous trade-off effect on the properties of smart ortho-functional benzoxazines. Polym. Chem. 2015, 6, 2541-2550. [CrossRef]

40. El-Mahdy, A.F.M.; Kuo, S.W. Direct synthesis of poly (benzoxazine imide) from an ortho-benzoxazine: Its thermal conversion to highly cross-linked polybenzoxazole and blending with poly (4-vinylphenol). Polym. Chem. 2018, 9, 1815-1826. [CrossRef]

41. Nagata, T.; Kurowarabi, K.; Kawauchi, T.; Matsumoto, A.; Furukawa, N.; Takeichi, T. Takeichi, Preparation of Imide-modified Benzoxazines and Characterization of Cured Films. J. Photopolym. Sci. Technol. 2015, 28, 145-150. [CrossRef] 
42. Lin, R.C.; Mohamed, M.G.; Hsu, K.C.; Wu, J.Y.; Jheng, Y.R.; Kuo, S.W. Multivalent photo-crosslinkable coumarin-containing polybenzoxazines exhibiting enhanced thermal and hydrophobic surface properties. RSC Adv. 2016, 6, 10683-10696. [CrossRef]

43. Mohamed, M.G.; Hsiao, C.H.; Luo, F.; Dai, L.; Kuo, S.W. Multifunctional polybenzoxazine nanocomposites containing photoresponsive azobenzene units, catalytic carboxylic acid groups, and pyrene units capable of dispersing carbon nanotubes. RSC Adv. 2015, 5, 45201-45212. [CrossRef]

44. Mohamed, M.G.; Hsiao, C.H.; Hsu, K.C.; Lu, F.H.; Shih, H.K.; Kuo, S.W. Supramolecular functionalized polybenzoxazines from azobenzene carboxylic acid/azobenzene pyridine complexes: Synthesis, surface properties, and specific interactions. RSC Adv. 2015, 5, 12763-12772. [CrossRef]

45. Zhang, Y.; Liu, X.; Zhan, G.; Zhuang, Q.; Zhang, R.; Qian, J. Study on the synergistic anticorrosion property of a fully bio-based polybenzoxazine copolymer resin. Eur. Polym. J. 2019, 119, 477-486. [CrossRef]

46. Phalak, G.A.; Patil, D.M.; Mhaske, S.T. Synthesis and characterization of thermally curable guaiacol based poly (benzoxazine-urethane) coating for corrosion protection on mild steel. Eur. Polym. J. 2017, 88, 93-108. [CrossRef]

47. Lin, S.C.; Wu, C.S.; Yeh, J.M.; Liu, Y.L. Reaction mechanism and synergistic anticorrosion property of reactive blends of maleimide-containing benzoxazine and amine-capped aniline trimer. Polym. Chem. 2014, 5, 4235-4244. [CrossRef]

48. Ruhi, G.; Modi, O.P.; Dhawan, S.K. Chitosan-polypyrrole-SiO 2 composite coatings with advanced anticorrosive properties. Synth. Met. 2015, 200, 24-39. [CrossRef]

49. Radhakrishnan, S.; Siju, C.R.; Mahanta, D.; Patil, S.; Madras, G. Conducting polyaniline-nano-TiO ${ }_{2}$ composites for smart corrosion resistant coatings. Electrochim. Acta 2009, 54, 1249-1254. [CrossRef]

50. Vakili, H.; Ramezanzadeh, B.; Amini, R. The corrosion performance and adhesion properties of the epoxy coating applied on the steel substrates treated by cerium-based conversion coatings. Corros. Sci. 2015, 94, 466-475. [CrossRef]

51. Chang, K.C.; Ji, W.F.; Lai, M.C.; Hsiao, Y.R.; Hsu, C.H.; Chuang, T.L.; Liu, W.R. Correction: Synergistic effects of hydrophobicity and gas barrier properties on the anticorrosion property of PMMA nanocomposite coatings embedded with graphene nanosheets. Polym. Chem. 2014, 5, 6865. [CrossRef]

52. Hegazy, A.M.; Badawi, M.; El-Rehim, S.S.; Kamel, W.M. Influence of copper nanoparticles capped by cationic surfactant as modifier for steel anti-corrosion paints. Egypt. J. Pet. 2013, 22, 549-556. [CrossRef]

53. Zhou, C.; Lu, X.; Xin, Z.; Liu, J.; Zhang, Y. Hydrophobic benzoxazine-cured epoxy coatings for corrosion protection. Prog. Org. Coat. 2013, 76, 1178-1183. [CrossRef]

54. Hegazy, M.A.; Hefny, M.M.; Badawi, A.M.; Ahmed, M.Y. Nanosilicon dioxide/o-phenylenediamine hybrid composite as a modifier for steel paints. Prog. Org. Coat. 2013, 76, 827-834. [CrossRef]

55. Zhou, C.; Lu, X.; Xin, Z.; Liu, J.; Zhang, Y. Polybenzoxazine/SiO 2 nanocomposite coatings for corrosion protection of mild steel. Corros. Sci. 2014, 80, 269-275. [CrossRef]

56. Dexter, S.C.; Gao, G. Effect of seawater biofilms on corrosion potential and oxygen reduction of stainless steel. Corrosion 1988, 44, 717-723. [CrossRef]

57. Nikravesh, B.; Ramezanzadeh, B.; Sarabi, A.A.; Kasiriha, S.M. Evaluation of the corrosion resistance of an epoxy-polyamide coating containing different ratios of micaceous iron oxide/Al pigments. Corros. Sci. 2011, 53, 1592-1603. [CrossRef]

58. Zhang, K.; Ishida, H. Smart synthesis of high-performance thermosets based on ortho-amide-imide functional benzoxazines. Front. Mater. 2015, 2, 5. [CrossRef]

59. Aramaki, K. Relation between Corrosion Inhibition Efficiency of Polar Organic Compounds for Some Non-transition Metals and the HSAB Principle. Corros. Eng. 1983, 32, 144-148. [CrossRef]

60. Lu, X.; Liu, Y.; Zhou, C.; Zhang, W.; Xin, Z. Corrosion protection of hydrophobic bisphenol A-based polybenzoxazine coatings on mild steel. RSC Adv. 2016, 6, 5805-5811. [CrossRef]

61. Kelly, R.G.; Scully, J.R.; Shoesmith, D.; Buchheit, R.G. Electrochemical Techniques in Corrosion Science and Engineering; CRC Press: Boca Raton, FL, USA, 2002.

62. Qu, L.; Xin, Z. Preparation, and surface properties of novel low surface free energy fluorinated silane-functional polybenzoxazine films. Langmuir 2011, 27, 8365-8370. [CrossRef] [PubMed]

63. Dong, H.; Xin, Z.; Lu, X.; Lv, Y. Effect of N-substituents on the surface characteristics and hydrogen bonding network of polybenzoxazines. Polymer 2011, 52, 1092-1101. [CrossRef] 
64. Hegazy, M.A.; Sami, R.M.; Labena, A.; Wadaan, M.A.M.; Hozzein, W.N. 4,4'-(((1E,5E)-pentane-1,5-diylidene) bis(azanylylidene))bis(1-dodecylpyridin-1-ium) bromide as a novel corrosion inhibitor in an acidic solution (Part I). Mater. Sci. Eng. C 2020, 110, 110673. [CrossRef] [PubMed]

65. Qi, K.; Sun, Y.; Duan, H.; Guo, X. A corrosion-protective coating based on a solution-processable polymer-grafted graphene oxide nanocomposite. Corros. Sci. 2015, 98, 500-506. [CrossRef]

66. Hegazy, M.A.; Abdallah, M.; Alfakeer, M.; Ahmed, H. Corrosion inhibition performance of a novel cationic surfactant for protection of carbon steel pipeline in acidic media. Int. J. Electrochem. Sci. 2018, 13, 6824-6842. [CrossRef]

67. Bentiss, F.; Traisnel, M.; Lagrenee, M. The substituted 1, 3, 4-oxadiazoles: A new class of corrosion inhibitors of mild steel in acidic media. Corros. Sci. 2000, 42, 127-146. [CrossRef]

68. Poorteman, M.; Renaud, A.; Escobar, J.; Dumas, L.; Bonnaud, L.; Dubois, P.; Olivier, M.G. Thermal curing of para-phenylenediamine benzoxazine for barrier coating applications on 1050 aluminum alloys. Prog. Org. Coat. 2016, 97, 99-109. [CrossRef]

69. Zulkifli, F.; Yusof, M.S.M.; Isa, M.I.N.; Yabuki, A.; Nik, W.W. Henna leaves extract as a corrosion inhibitor in acrylic resin coating. Prog. Org. Coat. 2017, 105, 310-319. [CrossRef]

Publisher's Note: MDPI stays neutral with regard to jurisdictional claims in published maps and institutional affiliations.

(C) 2020 by the authors. Licensee MDPI, Basel, Switzerland. This article is an open access article distributed under the terms and conditions of the Creative Commons Attribution (CC BY) license (http://creativecommons.org/licenses/by/4.0/). 